\title{
Gem corundum deposits in Vietnam
}

\section{Pham Van Long1, Hoàng Quang Vinh², Virginie Garnier', Gaston Giuliani ${ }^{4}$, Daniel Ohnenstetter ${ }^{3}$, Thérèse Lhomme ${ }^{5}$, Dietmar Schwarz ${ }^{6}$, Anthony Fallick7, Jean Dubessy ${ }^{5}$ and Phan Trong Trinh²}

1. Vietnam National Gem and Gold Corporation, 91 Dinh Tien Hoang Street, Hanoi, Vietnam

2. Institute of Geological Sciences, CNST, Nghia Dô, Câu Giây, Hanoi, Vietnam

3. CRPG/CNRS, UPR 2300, BP 20, 54501 Vandouvre, France

4. IRD and CRPG/CNRS, UPR 2300, BP 20, 54501, Vandouvre, France Author correspondence: giuliani@crpg.cnrs-nancy.fr

5. UMR 7566 G2R/CNRS, Université Henri-Poincaré, BP 239, 54506 Vandoeuvre, France

6. Gübelin Gemmological Laboratory, 102 Maihofstrasse, CH-6000 Lucerne 9, Switzerland

7. SUERC, Scottish Enterprise Technology Park, Rankine Avenue, East Kilbride G75 OQF, Scotland

Abstract: Since 1983, gem-quality rubies have been recovered from the Luc Yen and Quy Chau mining areas in northern Vietnam. Since 1991, 'basaltic'-type blue-green-yellow ('BGY') sapphires have been mined in southern Vietnam. This article briefly reviews the history and geology of these different areas and shows the importance of marble and basalt-type deposits. Other types of corundum occurrences are found in amphibolite, pegmatite, gneiss and metasomatite. The gemmological, chemical and isotopic characteristics of these different types of corundum are described.

The most notable features of rubies contained in marbles are that many crystals have blue colour zones, and inclusions of rutile, anhydrite and salts. The primary fluid inclusions are composed of carbon dioxide and hydrogen sulphide with native sulphur and diaspore daughter minerals. Sapphires from placers in basalts are characterized by inclusions of columbite, pyrochlore and baddeleyite. The trace element contents of corundums allow distinction of rubies in marbles from sapphires in basalts and metamorphic rocks. Rubies have high chromium $\left(0.54<\mathrm{Cr}_{2} \mathrm{O}_{3}<0.66\right.$ wt. \%) and low iron $(0.01<\mathrm{FeO}<0.07$ wt. $\%)$ contents. The geological origin of Vietnam corundums can be clearly determined from the isotopic composition of their structural oxygen, i.e. $\delta^{18} \mathrm{O}=21.0 \pm 0.9 \%$ for rubies in marbles and $\delta^{18} \mathrm{O}=6.6 \pm 0.4 \%$ for sapphires in basalts. 

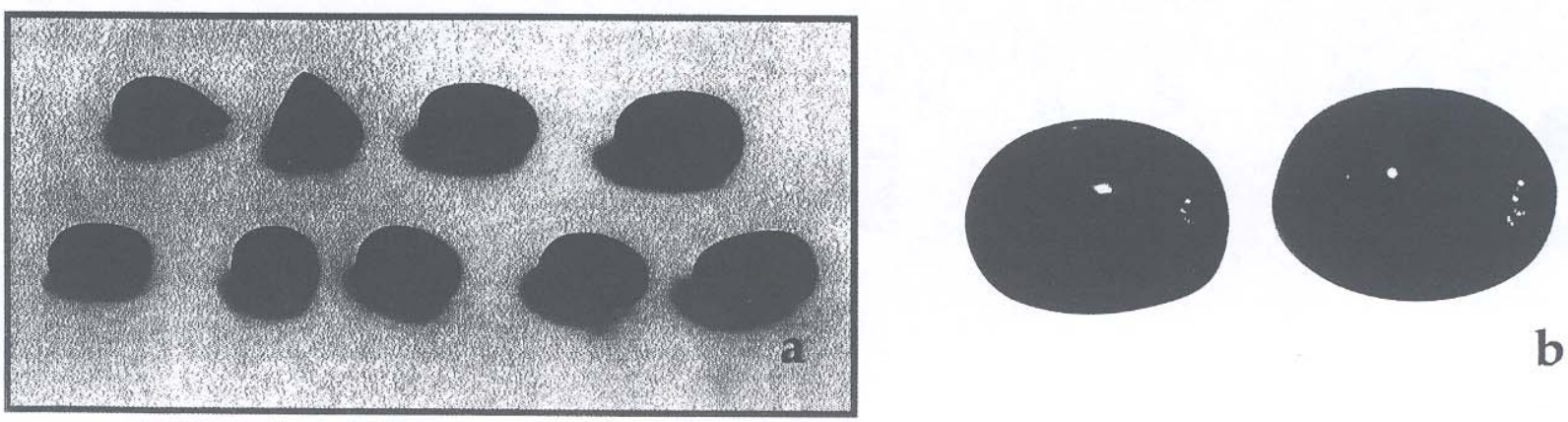

b

Figure 1: (a) Gem-quality rubies from the Quy Chau deposit in Vietnam. The samples range from 1.36 to $6.21 \mathrm{ct}$. (b) Two stars rubies from Tan Huong deposit (13.67 and 15.86 ct, respectively). Photographs by Pham Van Long.

\section{Introduction}

Gem corundums have been known in Vietnam since 1983. During the last ten years, Vietnam has become a significant ruby and sapphire-producing country in south-east Asia (Figure 1).

In this paper, the term ruby is used for $\mathrm{Cr}$-bearing corundum including pink and purple coloured crystals.

Development of the gem industry is due to the important programme of geological field mapping maintained by the Vietnamese government. These geological investigations resulted in the first discovery of rubies in marbles and in the development of prospecting programmes leading to the discovery of corundum-bearing placer deposits. At the same time, thousands of local peasants searched for ruby and sapphire and in 1991, alluvial sapphires related to basalts were found in Southern Vietnam. Scientific investigations of the genesis of these deposits led to several publications (Kane et al., 1991; Dao et al., 1996; Dao and Delaigue 2000, 2001; Garnier et al., 2002; Pham Van, 1999, 2002) and international workshops (Hofmeister et al., 2001). The aim of this paper is to present a detailed review of the main types of gem corundum deposits in Vietnam within their geological framework. Their gemmological and mineralogical properties are compared with the intention of finding features which would allow one to identify Vietnamese corundums after removal from their geological environment.

\section{Discovery of gem corundum in Vietnam}

Rubies and sapphires have been found and mined in many places in Vietnam (Figure 2). Rubies and blue sapphires are now exploited in the northern part of the country, respectively

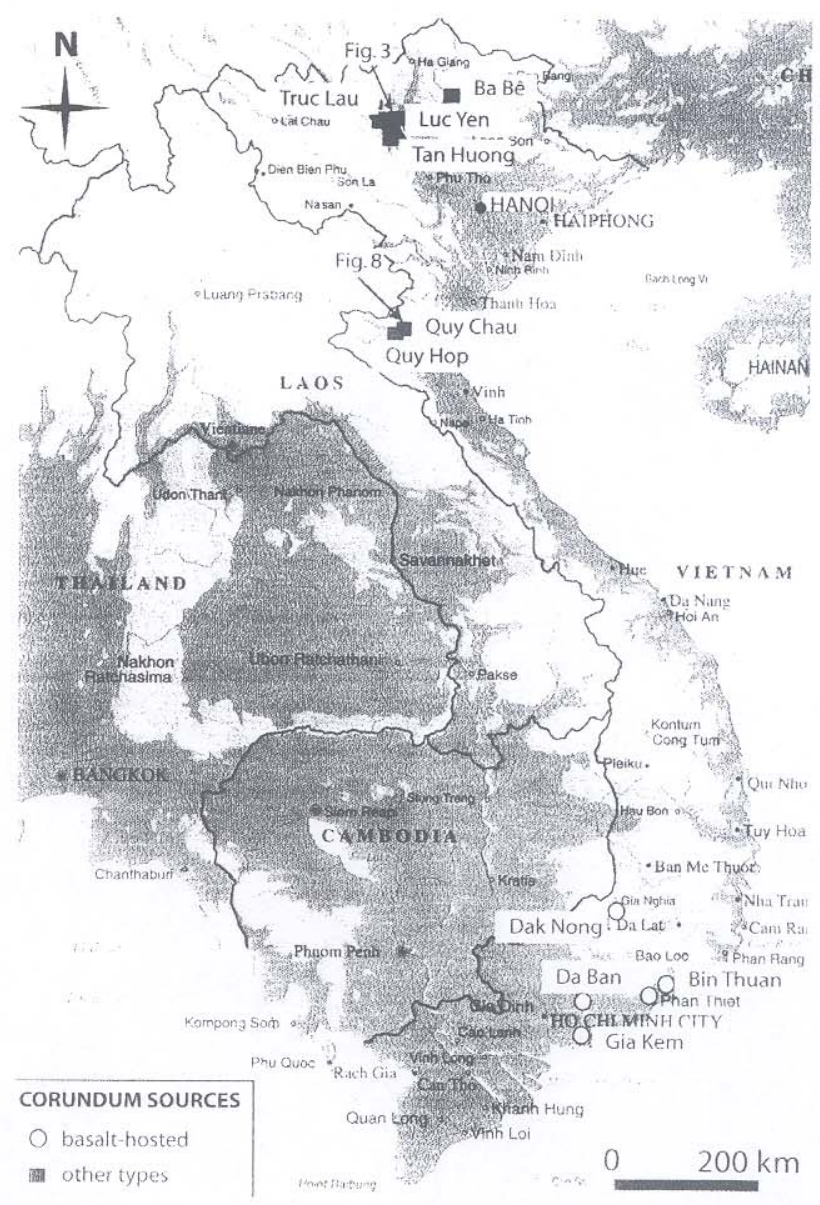

Figure 2: Map of Vietnam showing the location of basalt-hosted and other types of gem-corandum soutras. There are more details of areas indicated in Figures 3 and s. 


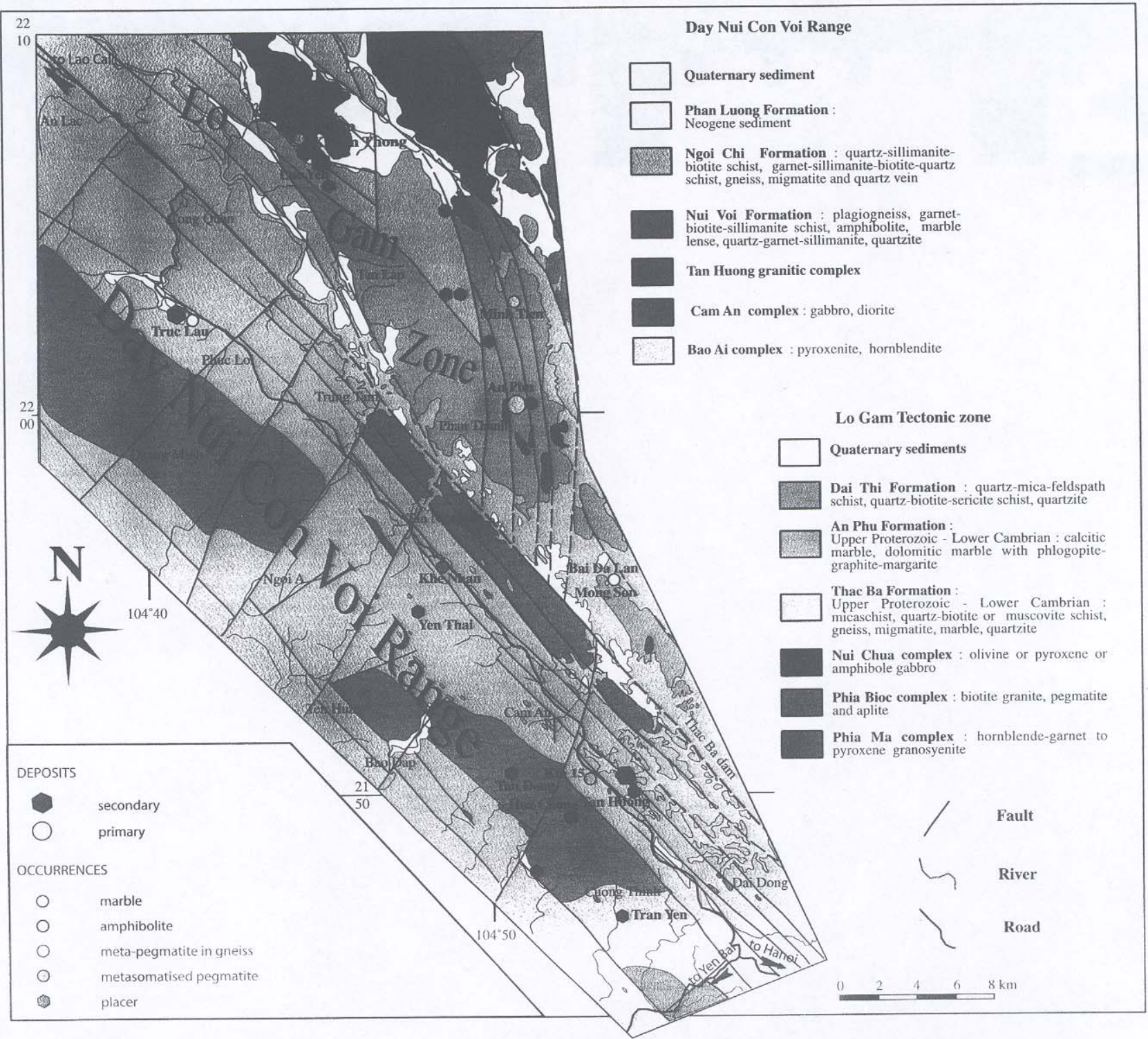

Figure 3: Geological map showing the major tectonic domains of the Red River shear zone with locations of the main corundum occurrences and deposits (adapted from Phan Trong and Hoáng Quang, 1997).

in the Yen Bai province from the Luc Yen and Yen Bai mining districts and in the Nghe An province from the Quy Chau deposits. In southern Vietnam, the corundums commonly include blue-green-yellow sapphires called 'BGY'-sapphires by Sutherland et al. (1998a), which are now exploited in the Dak Nong and Binh Thuan deposits in the Dak Lak and Lam Dong provinces respectively.

In 1983, ruby was discovered by a geologist during field mapping in the An Phu area (Luc Yen district), $270 \mathrm{~km}$ north of Hanoi (Figure 3). This corundum occurrence was investigated in detail and mining started in 1987. In March 1988, Vinagemco
(Vietnam gemstones company) was set up by the Vietnamese Government to control the mining activity. In the same year, Vinagemco and Boonsing-Hang Mining Company from Thailand established a joint-venture with the aim of mining the Khoan Thong placer (Figure 3). From November 1989 to March 1990 , the company recovered about $244 \mathrm{~kg}$ of gem-quality corundums. Almost all the production was cut and traded in Bangkok.

From 1990 to 1994, thousands of independent miners swarmed over the area and some new gem-quality corundum occurrences were found in places such as Minh Tien, Nuoc Ngap, Hin Om, Khau 

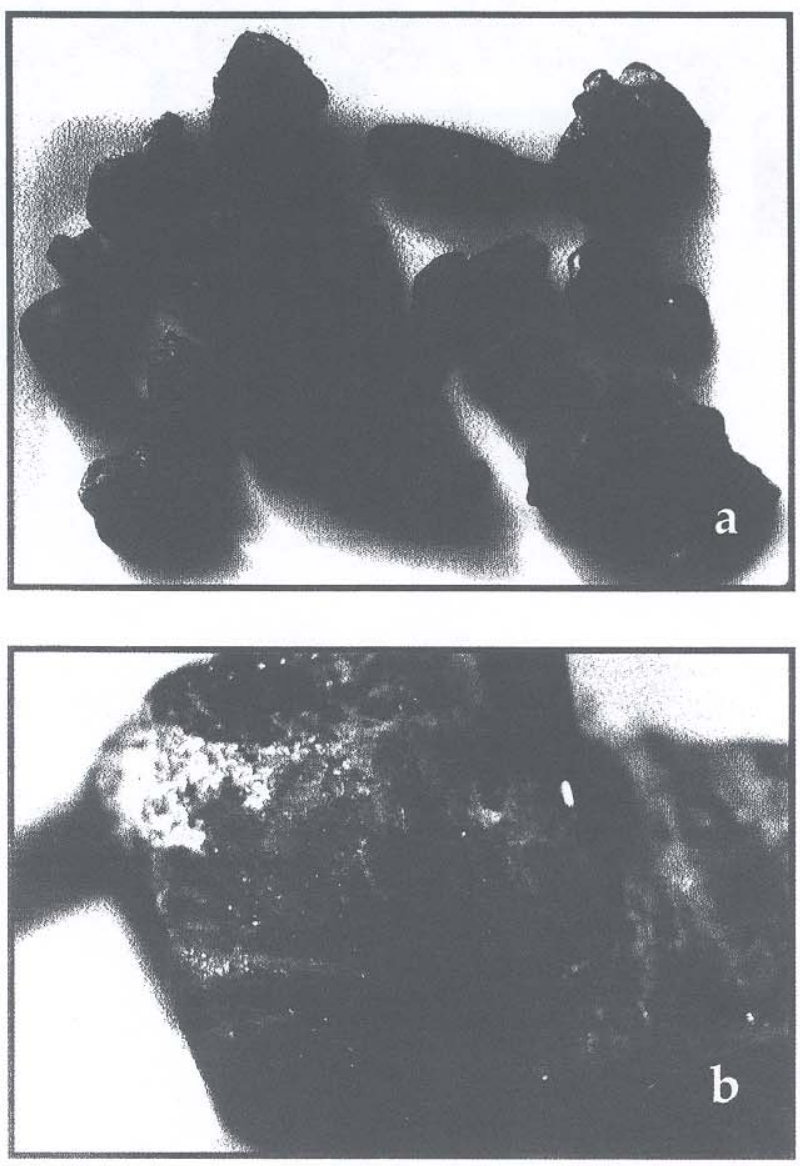

Figure 4: (a) Tan Huong ruby rough and one cabochon cut from ruby found in the Tan Huong placer located on the Day Nui Con Voi metamorphic range (northern Vietnam). (b) Ruby boulder from Tan Huong placer mine.

Photographed in 1998 by Gaston Giuliani.

Nghiem, Vang Sao, May Thuong and May Ha (Figure 3). At the same time rubies, sapphires and other minerals already sorted in placers were found, and with corundum crystals from the marbles, were brought to the gemstone market in Luc Yen.

Between 1994 and 1995, rubies were discovered in the Tan Huong and Truc Lau areas (Figure 3). These two mines are now directly managed by the Yen Bai Gem and Gold Company. Boulders of corundum up to $1 \mathrm{~kg}$ with zones of gem quality ruby are common in these placers (Figure $4 a, b$ ). In April 1997, two huge ruby crystals were found in the placer of Tan Huong with weights respectively of 2.58 and $1.96 \mathrm{~kg}$. These two stones of very high quality have been declared State treasure and can be displayed but not sold.
The Quy Chau mining district is located about $120 \mathrm{~km}$ north-west of the city of Vinh (Nghe An Province), about $300 \mathrm{~km}$ south of Hanoi (Figure 2). In 1988, rubies and blue sapphires were discovered in concentrates from alluvial deposits. Between 1989 and 1990, 10,000 miners migrated to the region from all over Vietnam. The illegal mining activities were outside the control of the Nghe An People's Committee and hundreds of people died when, in July 1990, there was a collapse in the Ho Ty mine (Billion hill mine, Figure 5a).

In addition to the monthly auctions of the rubies held by the provincial government, thousands of carats of rough rubies of high gem-quality have been sold to Thai traders. In an auction in 1996, a 56 ct rough ruby was sold for US $\$ 562,000$. In 1996, the management of the Quy Chau deposits was taken over by the Nghe An Gem and Gold Company. Since then, hundreds of $\mathrm{kg}$ of rubies have been recovered. Production was first displayed for auction on September 15, 2001, and since July 2002, weekly auctions have been held at the head office in Hanoi of the Vietnam National Gem and Gold Corporation (which organized the sale of gems mined by the Nghe An Gem and Gold Company).

Since 1991, 'BGY' sapphires have been found in many places in southern Vietnam. The first discovery occurred in Dak Nong (Dak Lak province) and the second in Di Linh (Lam Dong province). Very dark blue sapphires have been found also in Ham Thuan (Binh Thuan province). These sapphires range from transparent to translucent or opaque, but the percentage of transparent gem quality material has been very low. From 1992 to 1995 , the mine was exploited by local peasants and hundreds of $\mathrm{kg}$ of sapphires were illegally mined and sold. In 1996, the Tay Nguyen Gem and Gold Company was created to manage the mining of the deposits. The company carried out a detailed investigation and the mine opened in 1997. Although thousands of kilograms of sapphires were mined, they were mostly of very low gem quality and the mining activities in Tay Nguyen ceased finally in 2000 . 
Figure 5: The Quy Chau mining area. (a) View of the famous Billion hill mine which became a lake after the end of its exploitation in July 1990. (b) The Doi San placer in 1998. (c) View of the new dressing plant in October 2001. (d) The ruby-free skarn in Quy Chau consisting of alternating bands of green calc-silicates and brown to black phlogopite in marble.
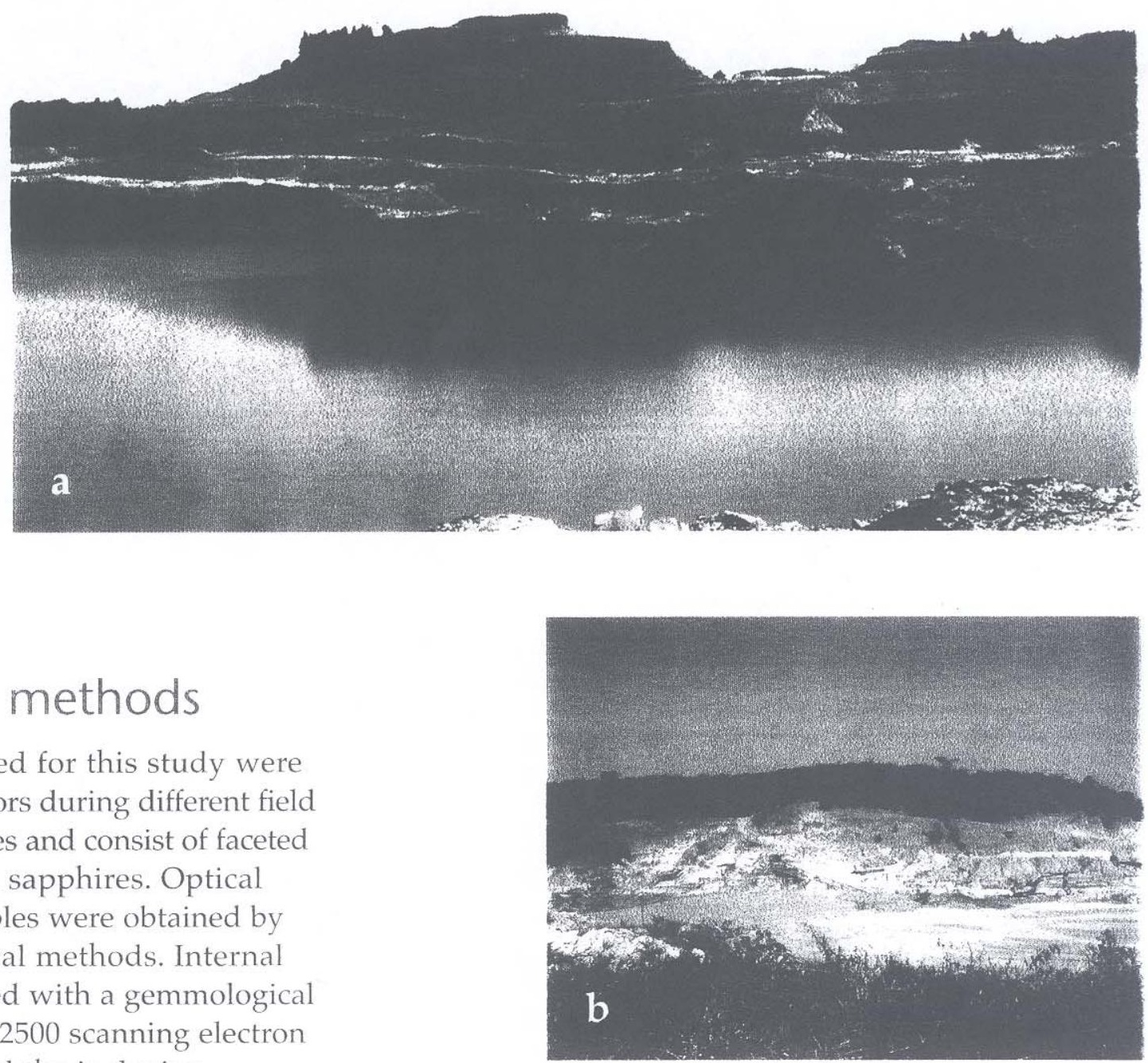

microprobe (SEM) and the inclusion

compositions obtained by energy-dispersive spectrometry (EDS). Rubies and sapphires from different geological environments and covering the full colour range of the samples were analysed by a CAMECA Camebax SX 50 electron microprobe with wavelength-dispersive spectrometers (WDS). The operating conditions of the electron microprobe were: an accelerating voltage of $10 \mathrm{kV}$, beam current of $10 \mathrm{nA}$, collection time of $10 \mathrm{~s}$ for major elements, and $20 \mathrm{kV}, 100 \mathrm{nA}, 30 \mathrm{~s}$ respectively for trace elements. The 'BGY' sapphires were also analysed by a semi-quantitative EDXRF method using a spectrace 5000 EDXRF system (Stern, 1984). The compositions of selected fluid inclusions and solid inclusions were obtained using a Labram Jobin-Yvon Raman microspectrometer. The excitation radiation was the $514.5 \mathrm{~nm}$ line of an Ar-ion laser (2020 Spectraphysics) that delivered $10-20 \mathrm{~mW}$ at the sample surface. The oxygen isotopic composition of rubies and sapphires was analysed following a modification of the laser-fluorination technique described by Sharp (1990).
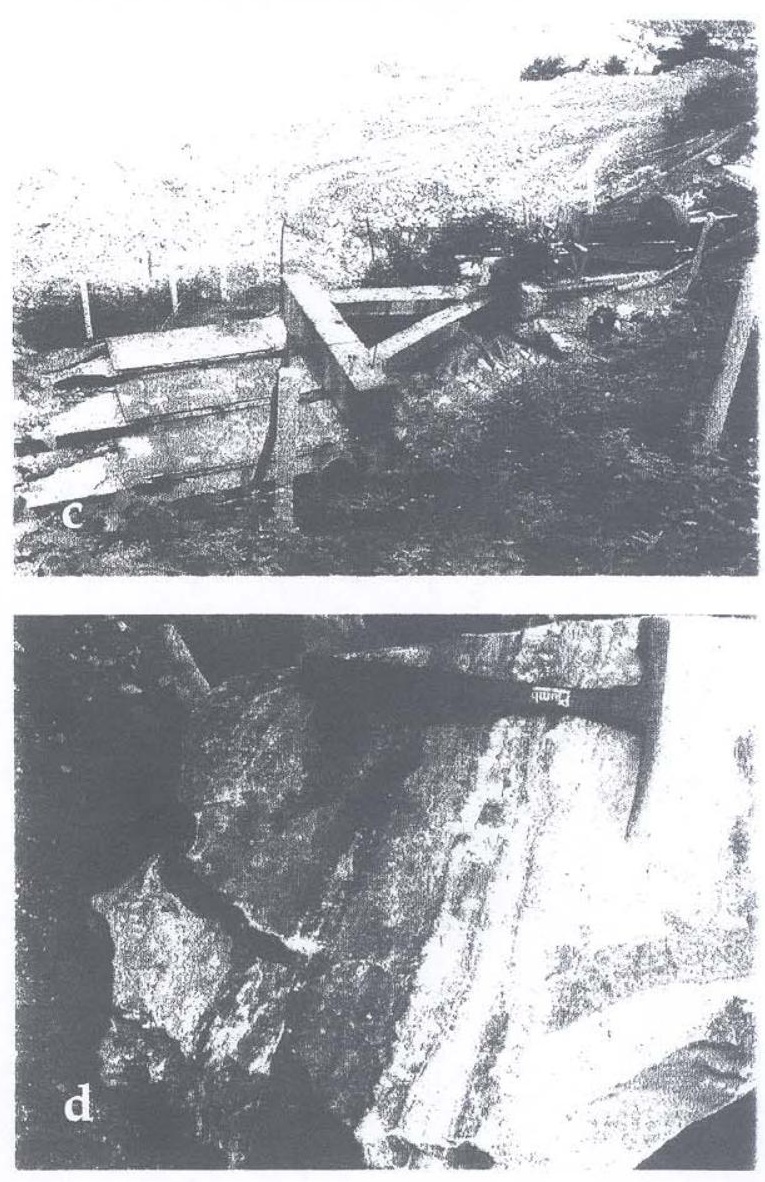


\section{Gem corundum deposits}

Two main types of gem-corundum deposits are found in Vietnam: rubies and sapphires in metamorphic rocks (northern Vietnam) and 'BGY'-sapphires in basalts (southern Vietnam).

\section{Corundum in northern Vietnam}

The Yen Bai and Luc Yen mining districts

1. The primary corundum occurrences of Yen Bai occur within the high-grade metamorphic gneisses forming the Day Nui Con Voi range (Figure 3), which extends to the southeast from the Ailao Shan in Yunnan (China). This range is bounded by lateral strike-slip faults forming the major Cenozoic geological discontinuity in East Asia known as the Ailao Shan-Red River shear zone.
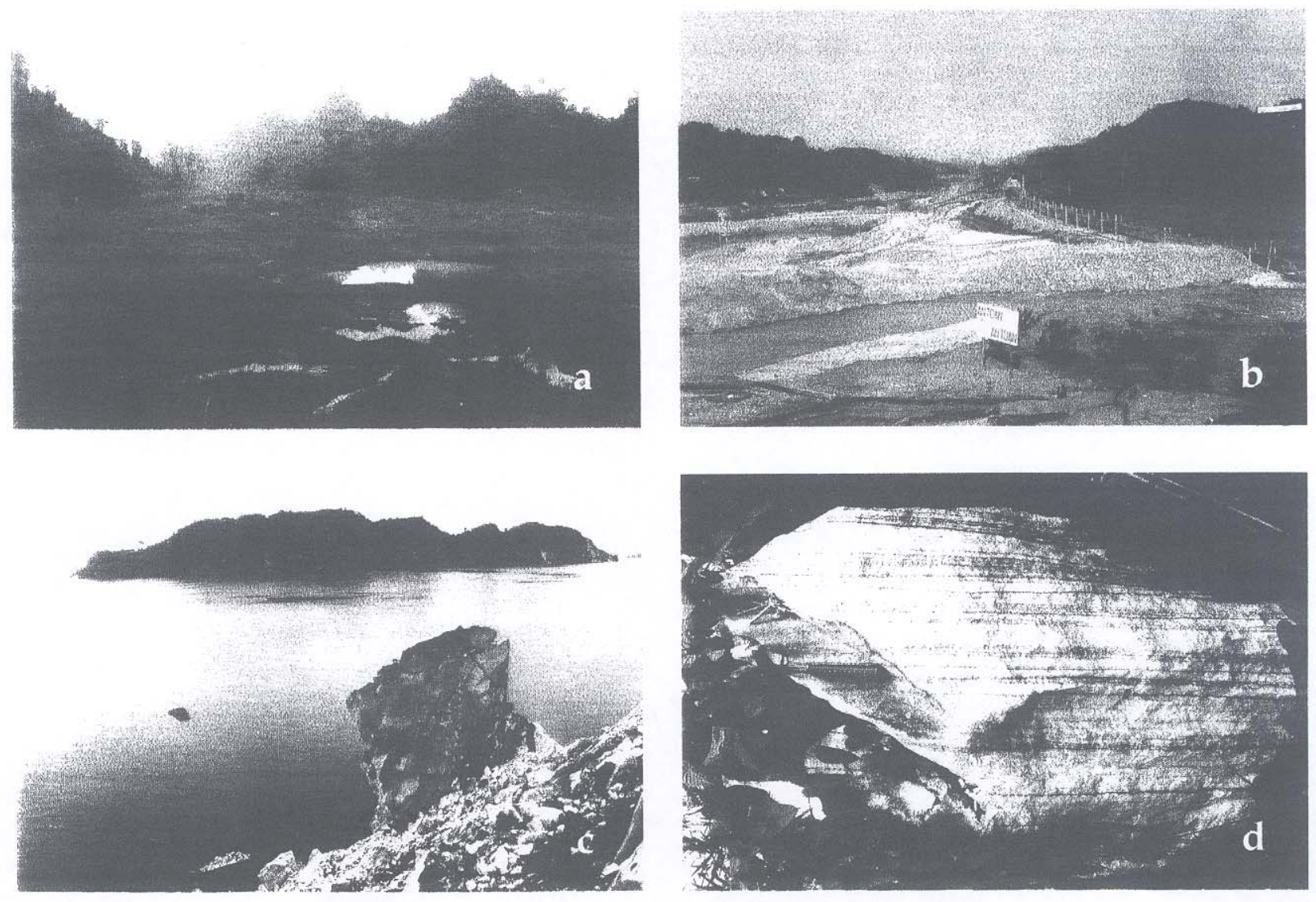

The Day Nui Con Voi range is composed of high-grade metamorphic rocks with sillimanite-biotite-garnet gneisses, mica schists with local successions of marbles and amphibolites. The deformation occurred under amphibolite facies conditions (pressure $=4-6.5 \mathrm{kbar}$ and temperature $=600-750^{\circ} \mathrm{C}$, Phan Trong et al., 1998; Leloup et al., 2001). Corundum occurs (A) as grey to blue sapphires in garnetsillimanite-mica schists and gneisses granitoid dykes (Truc Lau gneisses and Khe Nhan metapegmatite); (B) in amphibolites transformed by metasomatism into biotite schists with some layers containing centimetre-sized grey to darkgrey sapphires (north of Tan Huong mine, Km 15 occurrence; Figure 3); (C) as rubies in large marble boudins intergrown with containing leucosome and leucocratic

Figure 6: (a) Partial view of the Khoan Thong placer worked from 1989 to 1996 in the Luc Yen area. In the middle distance are karst hills showing the classical karst erosion patterns of marbles. (b) Part of the washing plant at the Tan Huong mine. (c) The' primary Bai Da Lan ruby deposit hosted in marbles viewed from the Thac Ba dam. (d) Typrical fresh section of banded marbles charaterized by alternating bands of white and dark marble consisting of carbonates, phlogopite and graphite. All photographs hij G. Giulinni in 1998. 


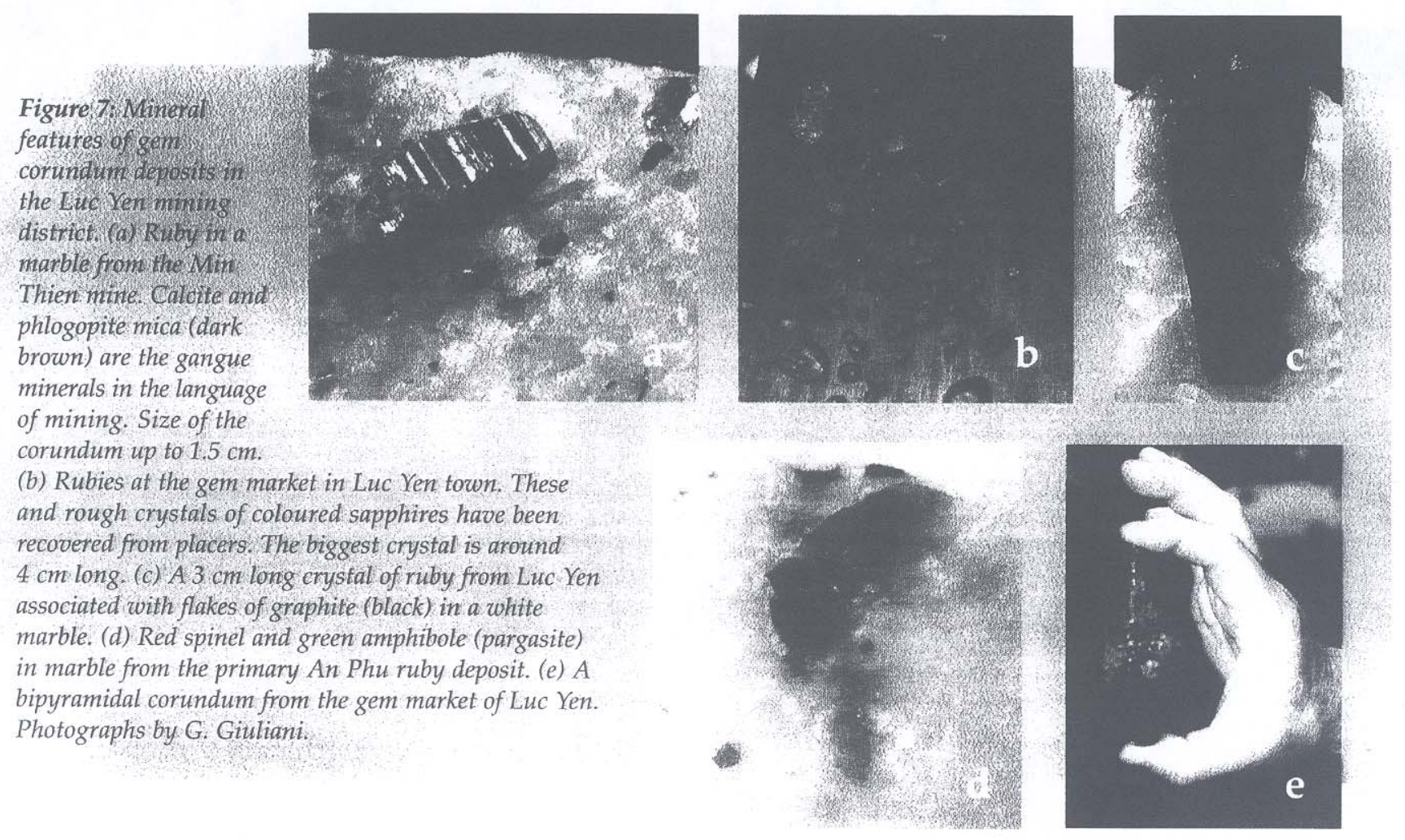

gneiss, mica schist and amphibole (Tan Huong drill cores). These marbles represent previous limestones interleaved with mudstones, which were sheared and metamorphosed during the tectonic activity along the Red River shear zone.

The gems occur in placer deposits along the shear zone such as at Tan Huong (Figure 6b) and Truc Lau. The paleoplacer of Truc Lau consists of $10 \mathrm{~m}$ of sediments overlying bedrock. The rubies and blue sapphires are contained in a gravel layer, $5 \mathrm{~m}$ thick, overlain by $3.5 \mathrm{~m}$ of Quaternary sediments and $1-1.5 \mathrm{~m}$ of soil. In 2002, up to two boulders $(1-2 \mathrm{~kg})$ of ruby were recovered every month in the paleoplacer. In the Tan Dong placer, assemblages of blue sapphire-margarite-plagioclase are the remnants of metasomatized pegmatites. Blue trapiche-like sapphires are found together with rubies and grey to pale blue sapphires in the placers of the Yen Bai area.

2. The ruby and sapphire deposits of Luc Yen nccur in moderate-to-high temperiture recrystallized marble units of Upper Proterozoic-tower Cambrian ige in the

eastern side of the Red River shear zone: the Lo Gam zone (Figure 3). Primary ruby occurs (A) as crystals disseminated within marbles (Figure 7c) with phlogopite (Figure 7a), dravite, margarite, pyrite, rutile, spinel, edenite, pargasite (Figure $7 d$ ) and graphite (Bai Da Lan, An Phu, Minh Tien, Nuoc Ngap, Luc Yen and Khoan Thong mines); (B) in veinlets associated with calcite, dravite, pyrite, margarite and phlogopite (An Phu mine); (C) in fissures with graphite, pyrite, phlogopite and margarite (Bai Da Lan mine, Figure 6c; Minh Tien region, Figure $6 d$ ). Gravels form placer deposits in karst topography (Figure 6a) and in alluvial fans in the Luc Yen valleys with blue, pale yellow and colourless sapphires, rubies and trapiche rubies (Figure $7 b$ ), and bipyramidal grey to brown sapphires (Figure 7e).

\section{The Bâ Be sapphire occurrence}

The Bâ Be sapphire occurrence is located in the Bac Kan province, $320 \mathrm{~km}$ north of Hanoi (Figure 3). It is close to the granite of Nui Chua and the gabbro-monzonite of Hoang Tri. The colourless to pale blue sapphire occurs in a pegmatite composed of quartz, K-feldspar and muscovite which intrudes schists and marbles. 


\section{The Quy Chau mining district}

In this area, located $200 \mathrm{~km}$ south of the Red River shear zone, the Bu Khang dome (Figure 8) consists of a broad antiform of Paleozoic and Mesozoic sedimentary and meta-sedimentary rocks overlying a core of mica schists, granitoid rocks, paragneisses and orthogneisses (Jolivet et al., 1999). The north-eastern part of the dome is limited by the major extensional Cenozoic shear zone of Quy Chau where the corundum deposits are located.

Rubies and blue sapphires have been mined since 1987 in the placer deposits of Doi Ty, Doi San, Mo Coi and Quy Hop (Figure 8). The corundums occur mainly in the Quy Chau area (A) as very rare (and non-economic) rubies disseminated in marbles associated with pyrite and graphite, and (B) in placers which form the economic deposits (Figures $5 a$, $b, c)$. In the Doi San and Doi Ty area, granitic intrusions linked with the injection of pegmatites are responsible for calciummagnesium-rich skarns in the surrounding marbles, amphibolites, gneisses and mica schists (Figure $5 d$ ). Ruby has not been found in either the skarn or the pegmatite and its genesis remains unclear. Blue sapphire is very rare.

\section{Corundum in southern Vietnam}

In the Dak Nong area, sapphires are found in weathered residual soils lying above alkali basalt flows and also in placer deposits in the river and stream fans (Figure 9a). Generally, the alluvial corundums resemble megacrysts found in situ in the basalts, but in Dak Nong, 'BGY'-sapphires have not been found in the host rocks. Their colours range from dark blue, through blue, green to yellow and some are colourless. The crystals occur as broken fragments but remains of the original habits are often present. Prisms and bipyramidal crystals may be up to $15 \mathrm{~mm}$ long and 2-4 mm wide.
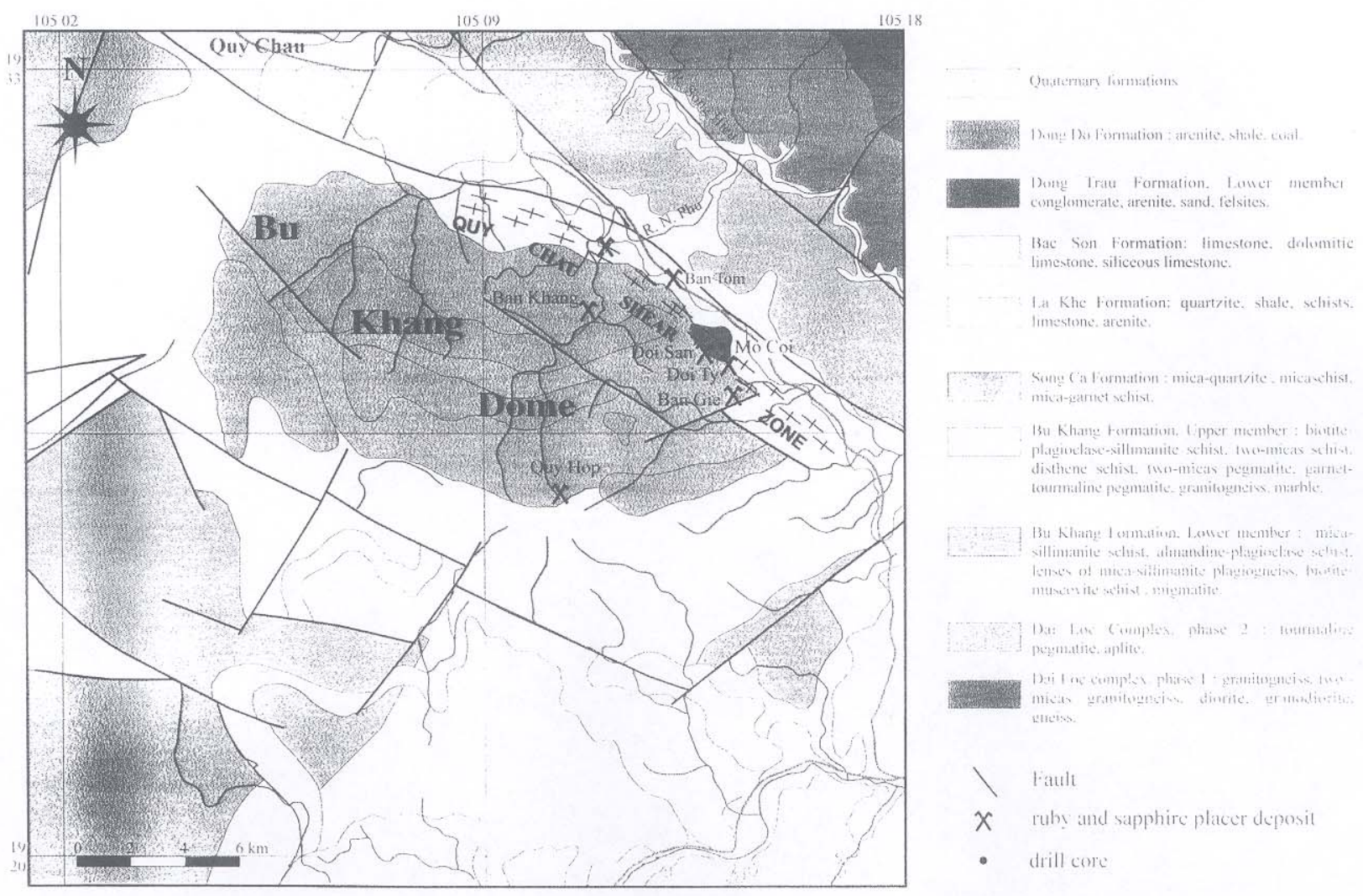

Figure 8: Geological map of the Bu Khang dome showing the location of the ruby and sapphire deposits of the (Ouy (hatu anti Quy Hop mining districts (map modified after Jolivet et al., 1999). 


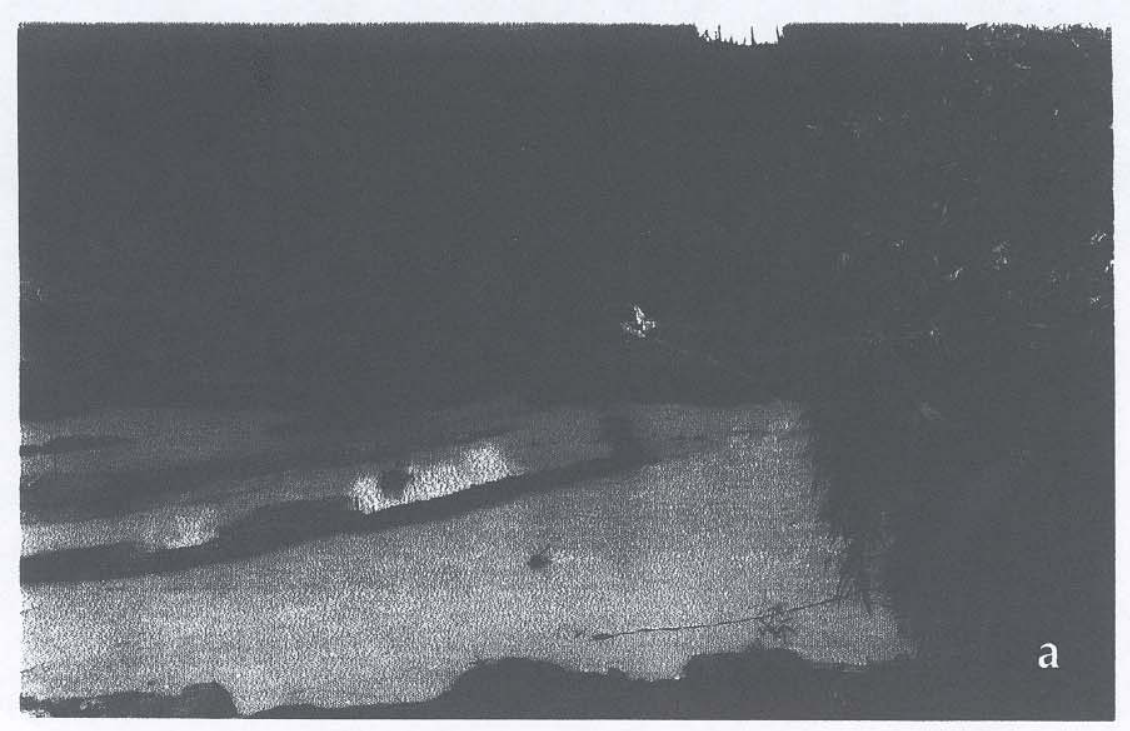

Figure 9: The 'BGY'-sapphire deposits related to basalts in southern Vietnam. (a) View in 2001 of the Dak Nong placer deposit located in alluvial fans.

(b) Corundum crystal found in alluvial soils above a basalt. (c) Alluvial corundum from the Bin Thuan area showing reflective surface attributed to high temperature corrosion which is indirect evidence of magma transport (small dots on the crystal surface). (d) Barrelshaped habit of a deep-blue sapphire originating from the Binh Thuan area. Photographs by G. Giuliani.
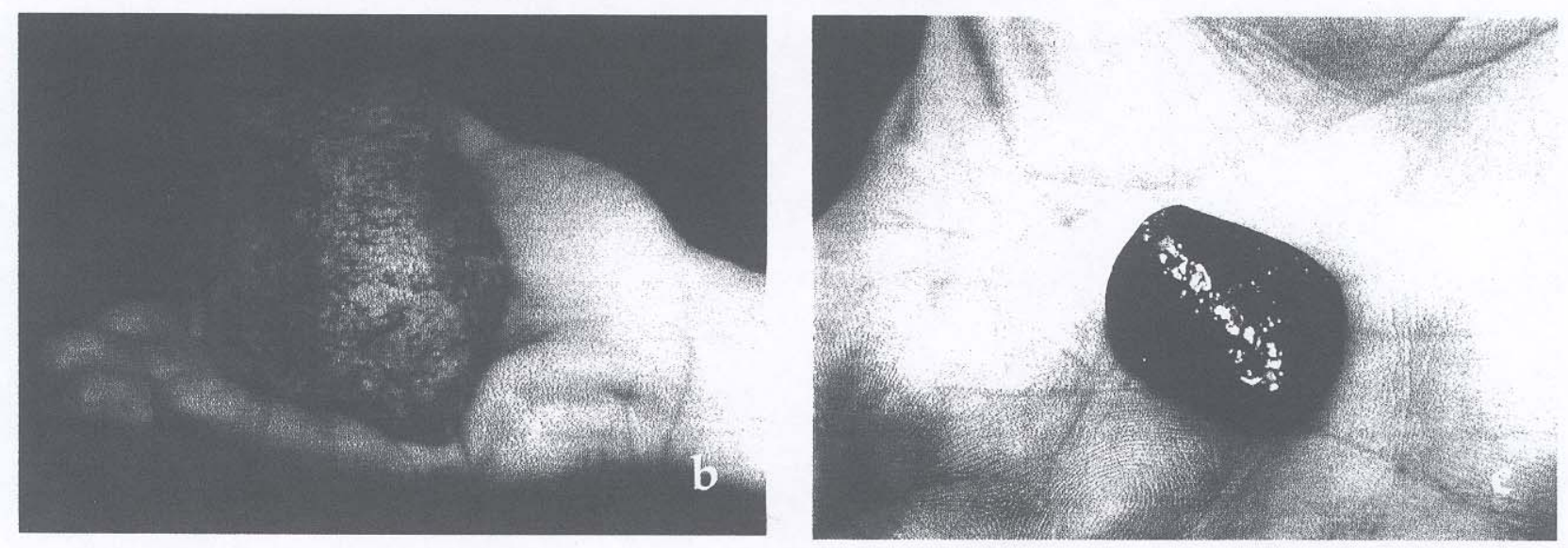

In the Binh Thuan area, the sapphires have barrel-shaped habits (Figrites 96, d). and are blue to very dark blue. Some crystals show rounded glassy-looking margins indicating high-temperature corrosion, indirect evidence of transport in a magma (Figure 9c). In the Da Ban area (Binh Thuan province) megacrysts of dark-blue sapphires are sometimes found within alkali-basalts.

\section{Gemmological properties}

\section{optical characteristics}

Colour: Corundums from the Quy Chau deposits range from moderate to high aturations of purplish red to purplish pink for ruby to blue for sapphire. In contrast, the corundums from the Yen Bai and Luc Yen deposits show all tones from red to pink (aby), and grey to blue and colourless to pale yellow sapphire. The rubies from Luc yen are usually less saturated than thome (w) ar? ouy Chat.

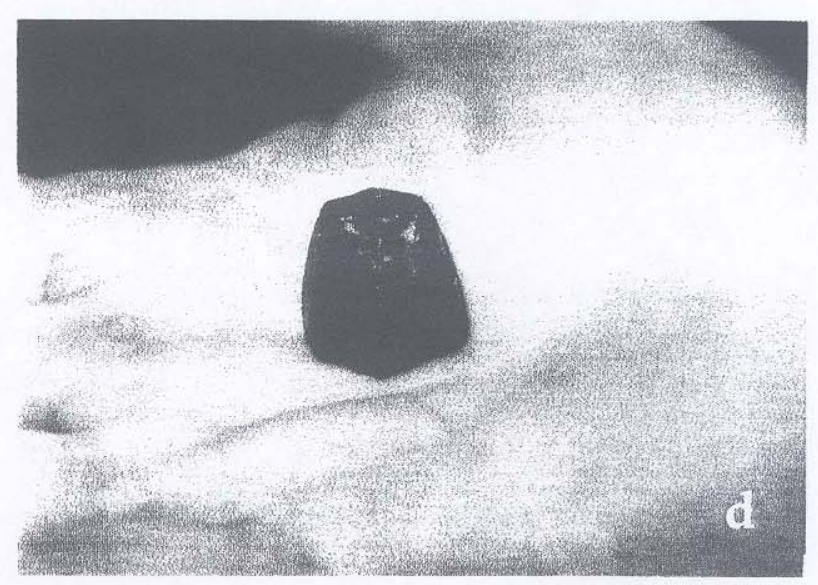

Corundum from southern Vietnam is commonly dark blue or greenish-blue and less commonly yellowish-blue. A small proportion of the corundums from the Binh Thuan deposit possess a very dark tone and yield deep blue cut stones.

Refractive index (RI): The RIs of rubies and sapphires were obtained in the Centre for Ciem and Gold Research and Identification (VCCG) using a Gem Duplex II instrument and all results were in the range 1.762 to 1.770 , birefringence 0.008 , which are nomal for corundum 
Specific gravity (SG): SGs were determined by the hydrostatic weighing method. The samples from Quy Chau (faceted and rough stones) gave values between 3.94 and 4.05; those from Luc Yen have values between 3.92 and 4.01. In both deposits, the SGs of the blue sapphires tend to be higher than those of red and pink rubies. Compared to the rubies and sapphires from Luc Yen and Quy Chau, most 'BGY'-sapphires from southern Vietnam gave SG values between 3.97 and 4.00 but some had SGs up to 4.08 , which are exceptionally high for corundum.

UV luminescence: All the red and pink samples from Quy Chau and Luc Yen appeared red when exposed both to longwave $(366 \mathrm{~nm})$ and short-wave (254 nm) ultraviolet radiation. The Quy Chau crystals tended to show stronger fluorescence than those from Luc Yen. Interestingly, some blue sapphires from Luc Yen (Khoan Thong area) also appeared red under both long- and short-wave ultraviolet radiation.

\section{Internal characteristics}

Twinning: The samples from Quy Chau and Luc Yen commonly show both lamellar and polysynthetic twinning.

Growth features: Straight and angular parallel growth features are quite common in rubies and sapphires from Luc Yen and Quy Chau. Other investigations (Kane et al., 1991) have described a swirl-like growth effect that is common in Burmese rubies and coloured sapphires from Vietnam.

Colour zoning: Some samples in this study show colour zoning. The colour zones range in size from narrow to broad areas generally parallel to the largest flat face of the sample. In many samples, dot-like and band-like colour zones are present. These are casily seen by immersion in methylene iodide, and even a blue zone can be distinguished against a background of red and pink zones.

The sapphires from southern Vietnam usually show alternation of colour bands indicating consecutive grow th tavers of light blue, colouters, steenish-biue or vellowish-blue.
Solid inclusions: The different solid inclusions identified in Vietnamese corundums are listed in Table I. The most common mineral inclusions found in the Luc Yen and Quy Chau rubies are calcite, dolomite, rutile, diaspore and phlogopite. These minerals are also found in the marbles. SEM studies also confirmed the common occurrences of crystals of anhydrite and other salts (of $\mathrm{Na}-\mathrm{Cl}$; $\mathrm{Ca}-\mathrm{Cl} ; \mathrm{K}-\mathrm{Cl}$ ). In contrast to the sapphires originating from basalts, rubies do not contain any columbite, ilmenite, pyrochlore or baddeleyite inclusions. In rubies, rutile is characteristically present as short needles and also as twinned plate-like crystals; less commonly, it appears as transparent orange brown or opaque crystals trapped along the growth zones. Zircons are found in corundums from both types of deposit and they have allowed indirect dating by the $\mathrm{U} / \mathrm{Pb}$ method. The calculated ages of corundum formation are between 38 and 34 Ma for the Luc Yen and 34 to $27 \mathrm{Ma}$ for the Quy Chau ruby deposits (Garnier et al., 2002), and 6 to $1 \mathrm{Ma}$ for the Dak Nong sapphires (Garnier et al., 2004).

Fluid inclusions: Three main types of fluid inclusions were recognized in the rubies from Luc Yen and Quy Chau on the basis of their relative chronology (Hoàng Quang et al., 1999; Giuliani ct al., 2003 a, b).

1. Type A fluid inclusions (primary) are 20 to $200 \mu \mathrm{m}$ long and occur as isolated or oriented clusters from the core to the rim of the crystals (Figures 10a, b); they are best observed in longitudinal sections. Type A inclusions are commonly two-phase fluids (liquid and vapour carbon dioxide phases) but some are associated in a single growth zone with single phase carbon dioxide-rich inclusions. The volumetric fraction of the carbon dioxide-rich liquid in the carbon dioxide-rich phase shows degrees of filling (F/c) ranging between 60 and $100 \%$ (Table II).

These inclusions display two kinds of morphology: (i) euhedral negative crystals with polygonal or square outlines found in planes parallel to the basal pinacoid (00001); (ii) Hat or broad tubes, some with a cap of a mineral inclusion. Diaspore is found eithey 
Table I: Solid inclusions identified in Luc Yen and Quy Chau rubies from marbles and in sapphires from basaltic deposits.

\begin{tabular}{|c|c|c|c|}
\hline Solid Inclusions & Luc Yen rubies & Quy Chau rubies & Basaltic sapphires \\
\hline Anatase & 2 & 2 & \\
\hline Andalusite & & 1 & \\
\hline Anhydrite & 8 & 8 & \\
\hline Anorthite & & 1 & \\
\hline Apatite & 6 & 6 & 1 \\
\hline Baddeleyite & & & 1 \\
\hline Boehmite & 6 & 6 & \\
\hline Brookite & 2 & 2 & \\
\hline Calcite & 6 & 6 & \\
\hline Columbite & & & 5 \\
\hline Corundum & 2 & 2 & \\
\hline Diaspore & 2 & 2 & \\
\hline Dolomite & 4 & 4 & \\
\hline Goethite & & & 5 \\
\hline Graphite & 2 & 2 & \\
\hline Halite & 8 & 8 & \\
\hline Hematite & 2 & & \\
\hline Hercynite & 2 & & \\
\hline Ilmenite & & & 5 \\
\hline Limonite & 7 & 7 & \\
\hline Margarite & 4 & 4 & 5 \\
\hline Monazite & 7 & & \\
\hline Muscovite & 2 & 2 & \\
\hline Nepheline & 7 & 7 & \\
\hline Nostrandite & 6 & & \\
\hline Phlogopite & 6 & 6 & \\
\hline Plagioclase & & & 5 \\
\hline Pyrite & 4 & 4 & \\
\hline Pyrochlore & & & 5 \\
\hline Pyrrhotite & 6 & & \\
\hline Rutile & 6 & 8 & \\
\hline Titanite & 7 & 7 & \\
\hline $\mathrm{Na}, \mathrm{Ca}, \mathrm{K}-\mathrm{Cl}$ salts & 8 & 8 & \\
\hline Spinel & 1 & 1 & \\
\hline Tourmaline & 2 & & \\
\hline Zircon & 2 & 2 & 1 \\
\hline Zoisite & & 2 & \\
\hline
\end{tabular}




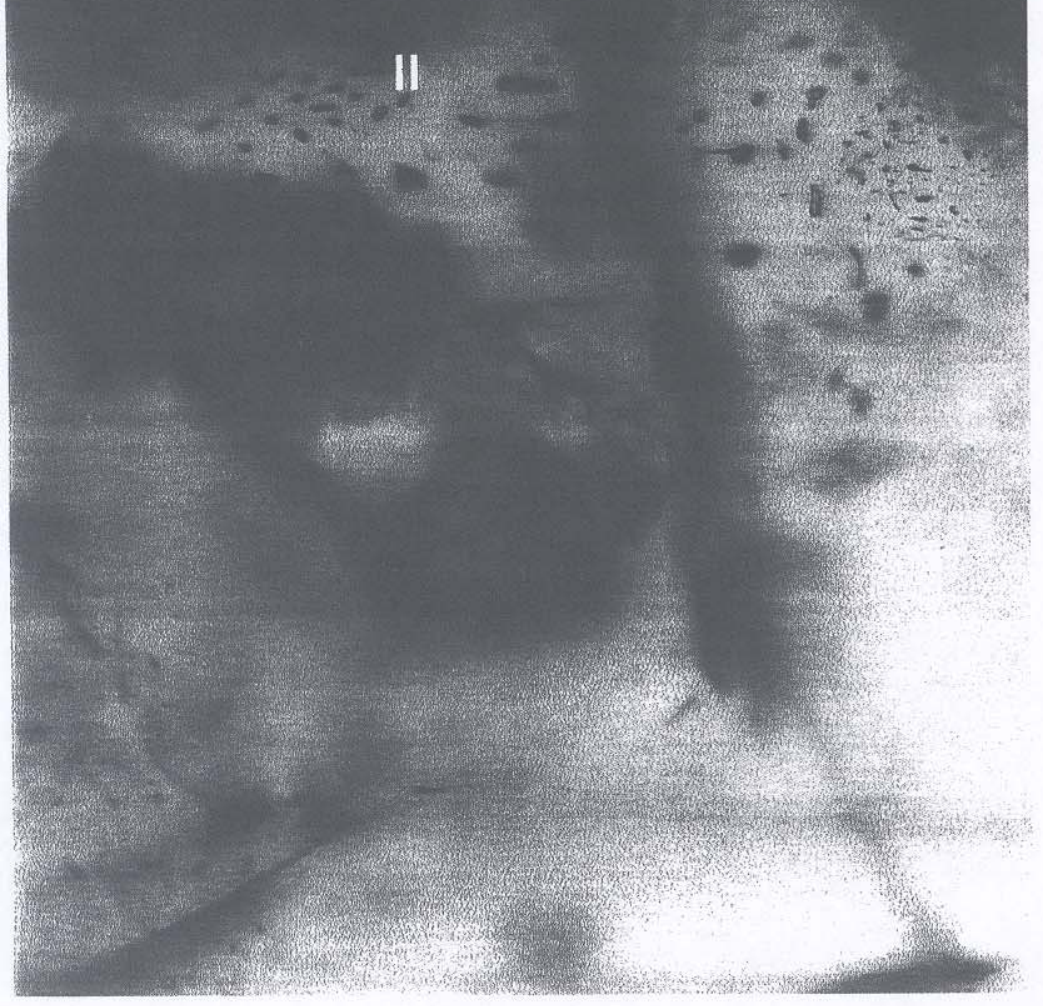

2. Type B fluid inclusions (pseudosecondary). These appear as small clusters or isolated in crystals and are mainly related to small intra-granular fractures. Planes of fluid inclusions are related to micro-cracks and subsequent fractures healed during crystal growth. At room temperature, Type B inclusions are single or two-phase (liquid and vapour carbon dioxide phases) with degree of filling (Flc) between 40 and $100 \%$. Inclusions may range in size from 20 to $125 \mu \mathrm{m}$ and display various shapes resembling negative crystals. Some of the negative crystals are capped by mineral inclusions (mainly calcite) at one end and contain calcite, rutile and daughter crystals of diaspore and native sulphur - all identified using Raman spectrometry.

3. Type C fluid inclusions (secondary). These occur along healed fracture planes which cross-cut several growth zones and show an elongated (Figure 10a) or roundedmorphology. Some inclusions are irregularly or crescent-shaped and they are interpreted as products of textural equilibration.

Figure 10: Photomicrographs of fluid inclusions in ruby from the Luc Yen area. (a) Isolated primary fluid inclusion (labelled I), $100 \mu \mathrm{m}$ long, contnining a liquid phase composed of $\mathrm{CO}, \mathrm{H}_{2} \mathrm{~S}$ and COS. Trail of secondary inclusions (labelled II) crosscutting the ruby crystal. (b) Primary two-phase fluid carbonic inclusion containing a liquid $(L)$ and vapour $(V)$. The size of the inclusion is 80 um long. Crossed nicols. Photographs by G. Giuliani.

as very rare solid inclusions present in fractures or as isolated prismatic crystals with a length up to $15 \mu \mathrm{m}$. Also, diaspore occurs in the fluid inclusion cavities as an invisible film, 2-3 $\mu \mathrm{m}$ thick, coating the wall of the whole inclusion cavity. The film was identified from its Raman lines at 331 and $448 \mathrm{~cm}^{-1}$, respectively (Figure 11 ). Native sulphur is present at room temperature, as very rare vitreous globules in the inclusions but it is commonly nucleated from an invisible thin layer during laser irradiation. $S_{8}$ was identified from its characteristic Raman peaks at 220 and $462 \mathrm{~cm}^{-1}$ (Figure $1 \%$ ). 


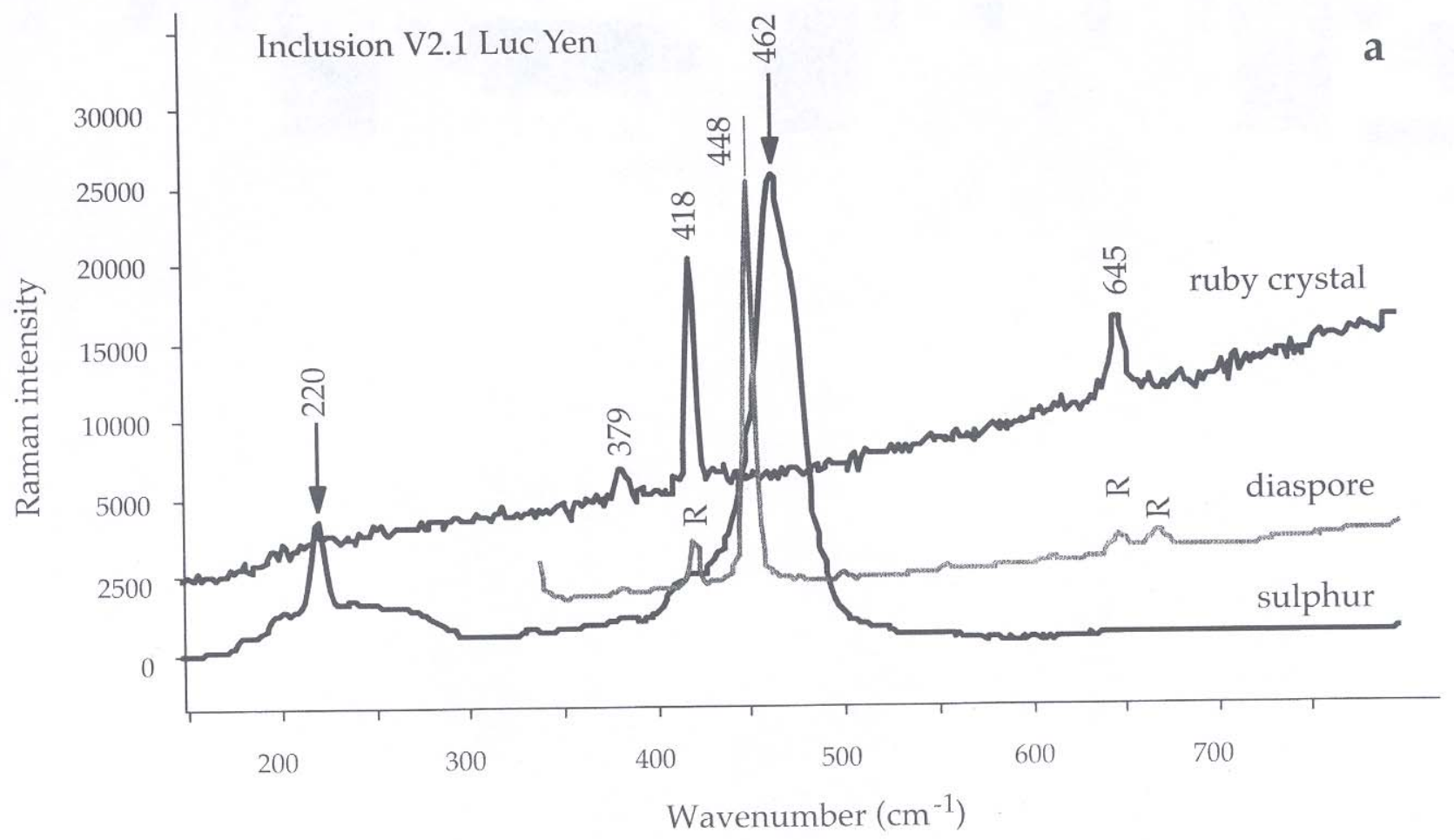

Figure 11: Raman spectra of the different phases analysed in fluid inclusion cavities in ruby. (a) Diaspore and amorphous sulphur detected in the same fluid inclusion (Luc Yen sample). The peaks of sulphur are obtained during irradiation of the liquid phase. The diaspore spectrum was obtained from the invisible diaspore film, 2-3 $\mu \mathrm{m}$ thick, which coats the wall of the fluid inclusions cavity. (b) Raman spectra of the volatile phase found in a primary fluid inclusion in a Quy Chau ruby. The components are $\mathrm{CO}_{2}$, $\mathrm{H}_{2} \mathrm{~S}, \mathrm{COS}, \mathrm{S}_{8}$ and diaspore as found for the fluid inclusions in Luc Yen rubies. $\mathrm{R}$ denotes peaks due to the ruby matrix.

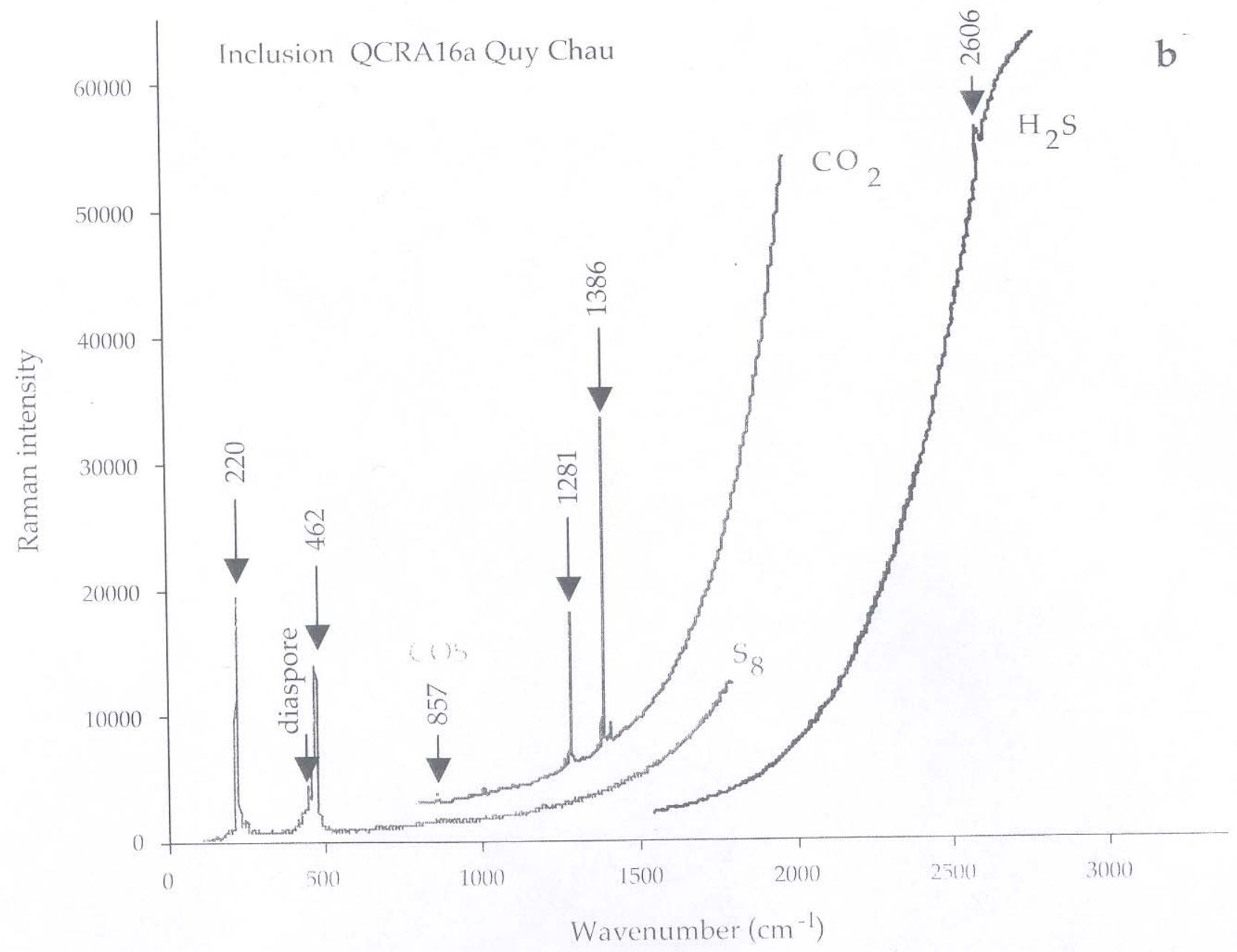


Table II: Microthermometric and Raman data for fluid inclusions in rubies from Luc Yen and Quy Chau.

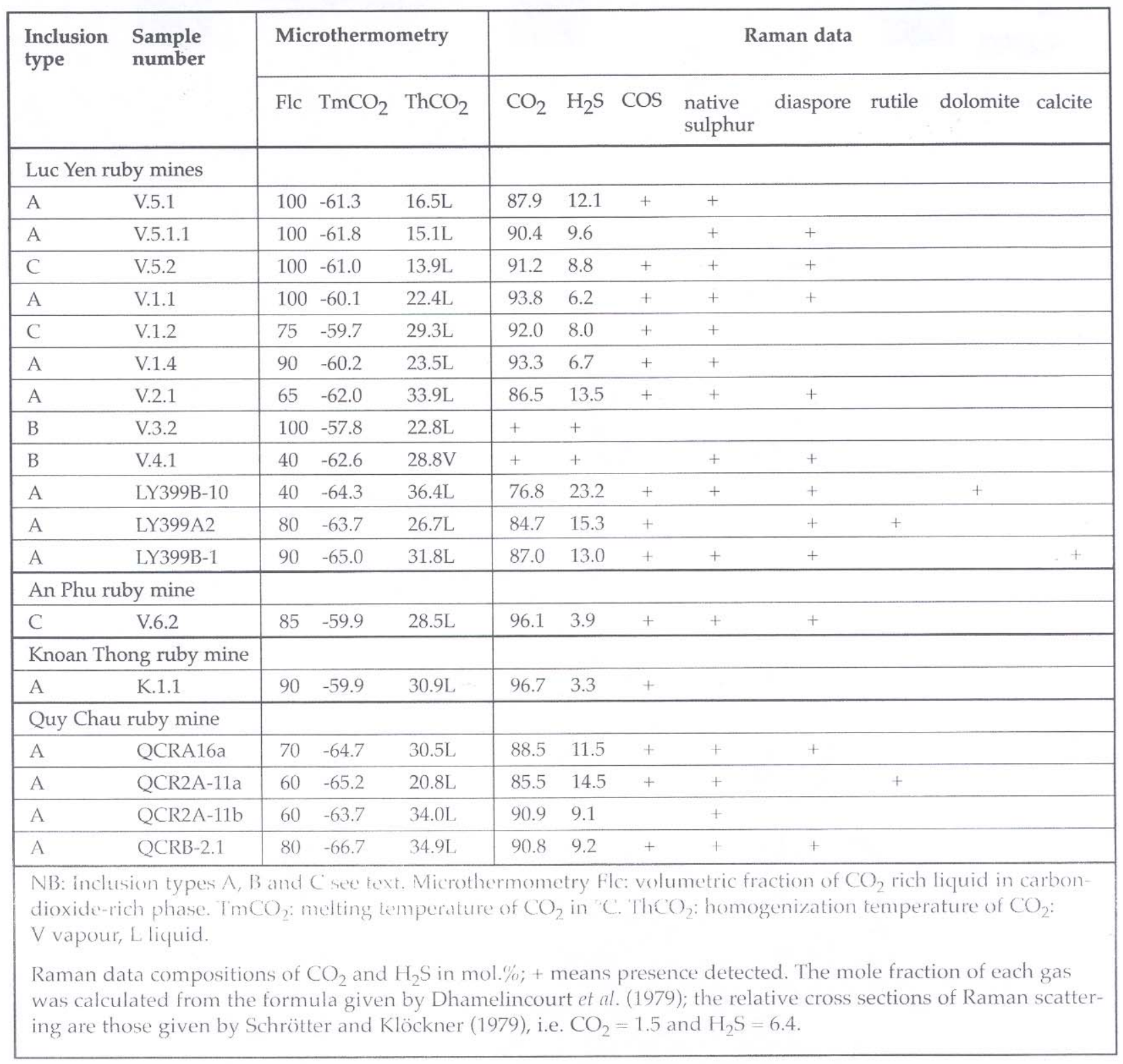

Their size ranges from 10 to $100 \mu \mathrm{m}$.

At room temperature, they contain one or two-phases and the volumetric fraction of the carbon dioxide-rich liquid in the carbon dioxide-rich phase is between 35 and $100 \%$.

Raman analyses of the three types of fluid inclusion revealed that the carbon dioxide phase is always composed of major $\mathrm{CO}_{2}$, with smaller amounts of $\mathrm{H}_{2} \mathrm{~S}$ and $\mathrm{COS}$ (Figure 11, Table II).

\section{Geochemical properties}

\section{Chemicil composition}

Chemical analyses of 128 corundums frem Vietnamese primary and secondary occurrences are shown in Table III. The correlation diagram of $\left(\mathrm{Cr}_{2} \mathrm{O}_{3} / \mathrm{Ga}_{2} \mathrm{O}_{3}\right)$ vs $\left(\mathrm{Fe}_{2} \mathrm{O}_{3} / \mathrm{TiO}_{2}\right)$ for corundums from the primary deposits from northern Vietnam is shown in Figure 12. This shows a clear separation of rubies in marbles from the coloured sapphires in gneiss, amphibolite and (meta-) pegmatite, with the one exception of the sapphires from the Khe Nhan pegmatite which fall within the field of the ruby-hosted marbles.

Corundums from the secondary deposits (placers) have clear chemical signatures. All the rubies and 'trapiche' rubies found in placers from northern Vietnam fall within the pripulation fickd defined by marble-hosted 
ruby. All the 'BGY' and colourless sapphires originating from Southern Vietnam and linked to placers in basalts define another distinct population (basaltic field) which is characterized by its very low chromium and gallium and high iron contents.

Chemical analyses obtained by the EDXRF method show that Dak Nong sapphires have higher gallium contents ( 0.03 to $0.045 \mathrm{wt} \%)$ and a wider range of $\mathrm{Fe}_{2} \mathrm{O}_{3}(0.65$ to $2.4 \mathrm{wt} \%$ ) than the other types of sapphire from basaltic areas in southern Vietnam, especially from Lam Dong Province (Figure 13). The chemical ratio $\mathrm{Cr}_{2} \mathrm{O}_{3} / \mathrm{Ga}_{2} \mathrm{O}_{3}$ vs $\mathrm{Fe}_{2} \mathrm{O}_{3} / \mathrm{TiO}_{2}$ of the sapphires match values recorded for 'basaltic' corundums by Sutherland et al. (1998a). Nevertheless, the wide variation of gallium content in the Dak Nong sapphires results in a correspondingly wide geochemical field (Figure 12).

The blue and colourless sapphires from Luc Yen and the blue (including the trapiche-like) sapphires from Yen Bai occupy a common field which partly overlaps the marble domain. Their field is defined by an $\mathrm{Fe}_{2} \mathrm{O}_{3} / \mathrm{TiO}_{2}$ ratio around 1 and low concentrations of $\mathrm{Cr}_{2} \mathrm{O}_{3}$ and $\mathrm{Ga}_{2} \mathrm{O}_{3}$. Although these sapphires were not observed in their parental rocks, they do not appear to originate

Table III: Electron microprobe analyses of rubies and sapphires from Vietnam.

\begin{tabular}{|c|c|c|c|c|c|c|c|c|c|c|c|c|}
\hline \multirow{2}{*}{\begin{tabular}{|l|}
$\begin{array}{l}\text { Corundum } \\
\text { from placers }\end{array}$ \\
$\mathrm{Wt} \%$
\end{tabular}} & \multicolumn{6}{|c|}{ Northern Vietnam } & \multicolumn{6}{|c|}{ Southern Vietnam } \\
\hline & \multicolumn{2}{|c|}{$\begin{array}{cc}\text { Quy Chau } \\
\text { ruby } \\
\\
(n=40)\end{array}$} & ruby & \multicolumn{2}{|c|}{$\begin{array}{cc} & \text { Luc Yen } \\
\sigma & \text { colourless } \\
(n=4) & \text { sapphires }\end{array}$} & \multirow{2}{*}{$\begin{array}{c}\begin{array}{c}\sigma \\
(\mathrm{n}=16)\end{array} \\
0.17\end{array}$} & \multirow{2}{*}{\begin{tabular}{|r}
$\begin{array}{r}\text { blue } \\
\text { sapphire }\end{array}$ \\
0.04
\end{tabular}} & \multicolumn{2}{|c|}{$\begin{array}{l}\text { Dak Nong } \\
\sigma \quad \text { green } \\
(n=14) \text { sapphire }\end{array}$} & \multirow{2}{*}{$\begin{array}{c}\begin{array}{c}\sigma \\
(\mathrm{n}=11)\end{array} \\
0.01\end{array}$} & \multicolumn{2}{|c|}{$\begin{array}{c}\text { Binh Thuan } \\
\text { black } \quad \sigma \\
\text { sapphire } \quad(n=6)\end{array}$} \\
\hline $\mathrm{TiO}_{2}$ & 0.03 & 0.03 & $0.01 \quad 0$. & 0.00 & 0.13 & & & 0.05 & 0.02 & & 0.04 & 0.04 \\
\hline $\mathrm{Al}_{2} \mathrm{O}_{3}$ & 99.28 & 0.72 & $99.76 \quad 0$. & 0.84 & 99.81 & 0.46 & 99.14 & 0.74 & 99.11 & 0.47 & 98.14 & 0.24 \\
\hline $\mathrm{Cr}_{2} \mathrm{O}_{3}$ & 0.58 & 0.55 & $0.54 \quad 0$. & 0.45 & 0.02 & 0.01 & 0.00 & 0.00 & 0.01 & 0.01 & 0.00 & 0.00 \\
\hline $\mathrm{Fe}_{2} \mathrm{O}_{3}$ & 0.07 & 0.07 & $0.01 \quad 0$. & 1.00 & 0.15 & 0.16 & 1.35 & 0.34 & 1.19 & 0.39 & 1.86 & 0.19 \\
\hline $\mathrm{V}_{2} \mathrm{O}_{3}$ & 0.02 & 0.05 & $0.07 \quad 0$. & .01 & 0.01 & 0.00 & 0.00 & 0.00 & 0.00 & 0.00 & 0.00 & 0.00 \\
\hline $\mathrm{Ga}_{2} \mathrm{O}_{3}$ & 0.01 & 0.00 & $0.01 \quad 0$. & 0.02 & 0.01 & 0.00 & 0.03 & 0.01 & 0.03 & 0.00 & 0.03 & 0.00 \\
\hline $\mathrm{MgO}$ & 0.00 & 0.00 & $0.00 \quad 0$. & 0.00 & 0.00 & 0.00 & 0.00 & 0.01 & 0.00 & 0.00 & 0.01 & 0.01 \\
\hline Total & 99.99 & 0.56 & $100.40 \quad 0$. & 0.63 & 100.13 & 0.41 & 100.56 & 0.74 & 100.36 & 0.47 & 100.08 & 0.11 \\
\hline \multirow{2}{*}{$\begin{array}{l}\text { Corundum } \\
\text { from primary } \\
\text { deposits }\end{array}$} & \multicolumn{2}{|c|}{ Luc Yen } & \multicolumn{6}{|c|}{ Yen Bai } & \multicolumn{2}{|c|}{$\mathrm{Ba} \mathrm{Be}$} & & \\
\hline & \multicolumn{2}{|c|}{$\begin{array}{l}\text { Luc Yen } \\
\text { marble }\end{array}$} & \multicolumn{2}{|c|}{$\begin{array}{c}\text { Tan Dong } \\
\text { metapegmatite }\end{array}$} & \multicolumn{2}{|c|}{$\begin{array}{l}\text { Tan Hung } \\
\text { amphibolite }\end{array}$} & \multicolumn{2}{|c|}{$\begin{array}{l}\text { Truc Lau } \\
\text { pegmatite }\end{array}$} & \multicolumn{2}{|c|}{$\begin{array}{c}\mathrm{Ba} \mathrm{Be} \\
\text { pegmatite }\end{array}$} & & \\
\hline Wt $\%$ & ruby & $\begin{array}{c}\sigma \\
(n=29)\end{array}$ & $\begin{array}{r}\text { blue } \\
\text { sapphire }\end{array}$ & $\begin{array}{c}\sigma \\
(n=8)\end{array}$ & $\begin{array}{r}\text { blue } \\
\text { sapphire }\end{array}$ & $\begin{array}{c}\sigma \\
(n=7)\end{array}$ & $\begin{array}{r}\text { blue } \\
\text { sapphire }\end{array}$ & $\begin{array}{c}\sigma \\
(n=8)\end{array}$ & $\begin{array}{r}\text { blue } \\
\text { sapphire }\end{array}$ & $\begin{array}{c}\sigma \\
(n=4)\end{array}$ & & \\
\hline $\mathrm{TiO}_{2}$ & 0.02 & 0.01 & 0.19 & 0.18 & 0.00 & 0.00 & 0.01 & 0.00 & 0.00 & 0.00 & & \\
\hline $\mathrm{Al}_{2} \mathrm{O}_{3}$ & 99.42 & 0.64 & 99.31 & 0.71 & 99.04 & 0.48 & 99.19 & 0.43 & 99.90 & 0.27 & & \\
\hline $\mathrm{Cr}_{2} \mathrm{O}_{3}$ & 0.37 & 0.58 & 0.00 & 0.00 & 0.01 & 0.00 & 0.00 & 0.00 & 0.00 & 0.00 & & \\
\hline $\mathrm{Fe}_{2} \mathrm{O}_{3}$ & 0.12 & 0.01 & 0.67 & 0.15 & 0.94 & 0.07 & 1.31 & 0.06 & 0.44 & 0.01 & & \\
\hline $\mathrm{V}_{2} \mathrm{O}_{3}$ & 0.01 & 0.01 & 0.00 & 0.00 & 0.00 & 0.00 & 0.00 & 0.00 & 0.00 & 0.00 & & \\
\hline $\mathrm{Ga}_{2} \mathrm{O}_{3}$ & 0.01 & 0.01 & 0.03 & 30.00 & 0.01 & 0.00 & 0.02 & 0.00 & 0.02 & 0.00 & & \\
\hline $\mathrm{MgO}$ & 0.02 & 0.01 & 0.01 & 0.00 & 0.00 & 0.00 & 0.00 & 0.00 & 0.00 & 0.00 & & \\
\hline Total & 99.87 & 0.40 & 100.21 & 0.72 & 100.01 & 0.47 & 100.53 & 0.46 & 100.36 & 0.27 & & \\
\hline
\end{tabular}




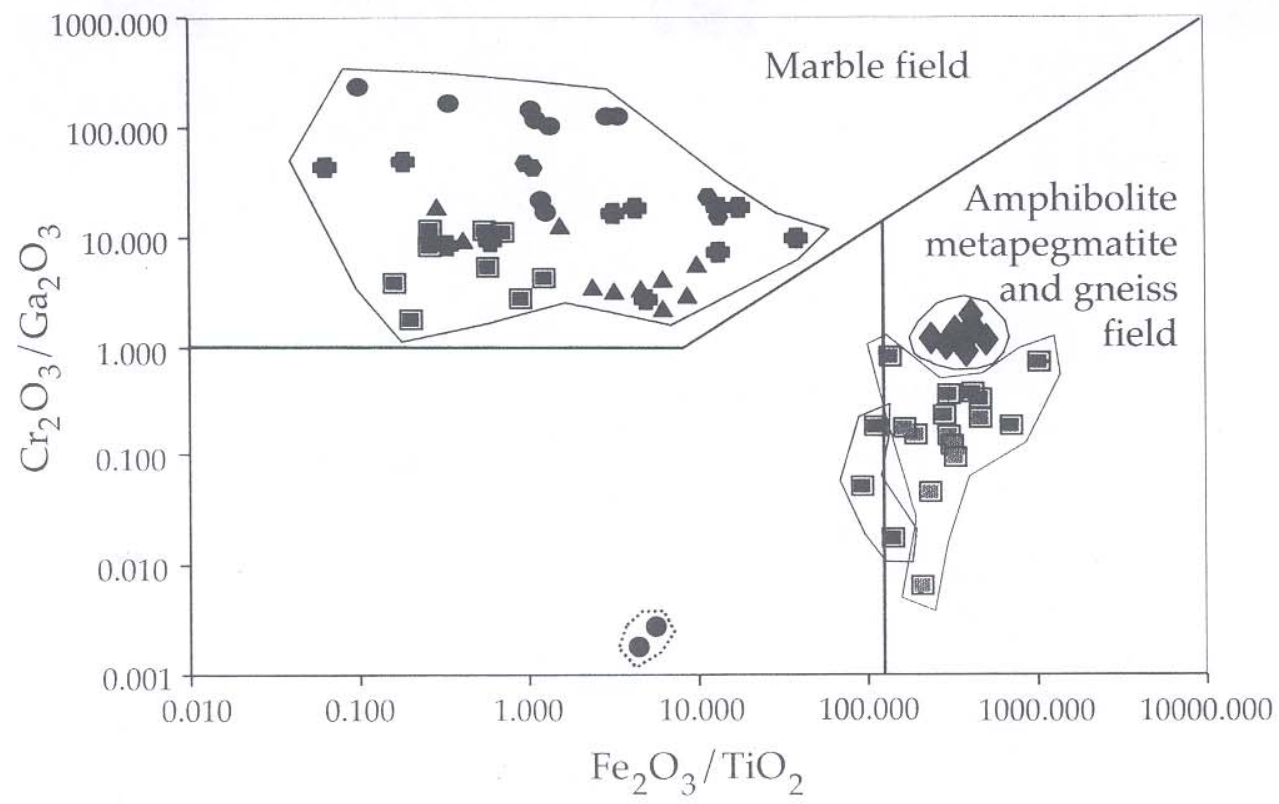

\begin{tabular}{|lll|}
\hline marble & pegmatite & metamorphic \\
- Nuoc Ngap & Khe Nhan & Truc Lau gneiss \\
Bai Da Lan & $\square$ BaBê & $\mathrm{Km} 15$ \\
Minh Tien & Truc Lau & \\
$\square$ An Phu & - Tan Dong blue & Primary deposits \\
& &
\end{tabular}

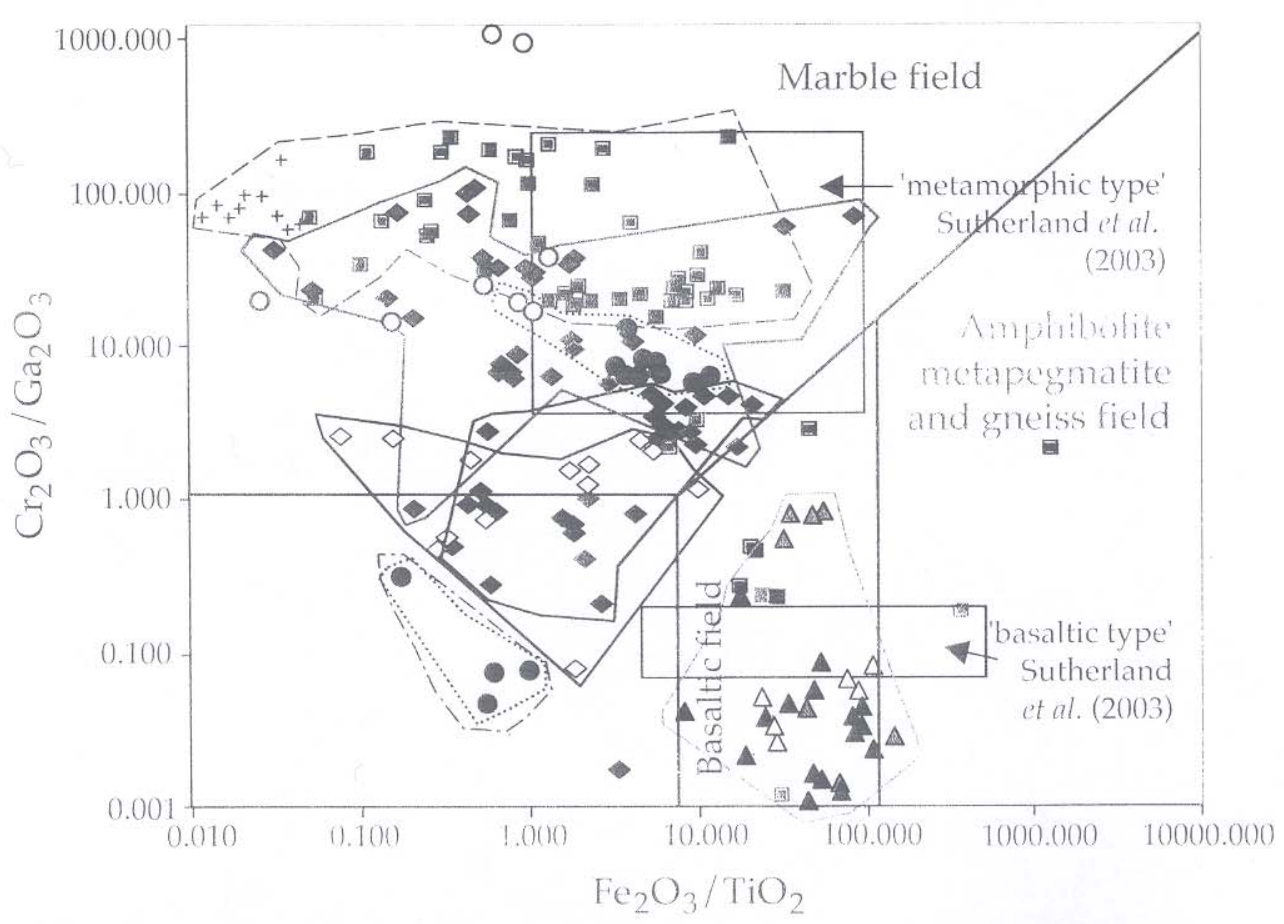

\begin{tabular}{|c|c|c|c|}
\hline $\begin{array}{l}\text { Quy Chau } \\
\text { 回 ruby } \\
+ \text { "trapiche } \\
\text { Quy Hop } \\
\text { @ blue sappl } \\
\text { (ai green sapt }\end{array}$ & $\begin{array}{l}\text { Tan Huong } \\
\text { blue sapphire } \\
\text { luby "trapiche" ruby } \\
\text { o ruby } \\
\text { iire } \\
\text { hire }\end{array}$ & $\begin{array}{l}\text { Luc Yen } \\
\Rightarrow \text { ruby } \\
\Rightarrow \text { "trapiche" ruby } \\
\Rightarrow \text { blue sapphire } \\
\Rightarrow \text { purple sapphire } \\
\Rightarrow \text { colourless sapphire }\end{array}$ & $\begin{array}{l}\text { Dak Nong } \\
\Delta \text { colourless sapphire } \\
\Delta \text { green sapphire } \\
\Delta \text { blue sapphire } \\
\Delta \text { yellow sapphire }\end{array}$ \\
\hline & $\begin{array}{l}\text { Tran Yen } \\
0 \text { ruby } \\
0 \text { purple sapphir }\end{array}$ & $\begin{array}{l}\text { An Phu } \\
\text { re "trapiche" ruby }\end{array}$ & $\begin{array}{l}\text { Bin Thuan } \\
\text { A deep blue sapphire }\end{array}$ \\
\hline
\end{tabular}


from marbles, gneiss, amphibolite or pegmatite. Their origin is unclear but the presence of the primary Tan Dong blue sapphire in the same field could indicate that some of these blue sapphires could be related to metasomatic alteration of pegmatites or other metamorphic rocks (hydrothermal field?).

The Tran Yen rubies originated probably from marbles; but different Quy Hop sapphires from placers in the Bu Khang dome plot in the basaltic, gneiss, amphibolite and metapegmatite fields and could come from a range of sources.

\section{Oxygen isotope geochemistry}

The rubies from Luc Yen have oxygen isotopic compositions $\left(\delta^{18} \mathrm{O}\right.$, in "\%o versus SMOW) between 19.3 and 22.4\% (average $\delta^{18} \mathrm{O}=21.0 \pm 0.9 \%$, 8 samples) and are in the same range as those from Quy Chau (average $\delta^{18} \mathrm{O}=22.2 \pm 0.05 \%$, 3 samples). The oxygen values of the rubies fall within the oxygen isotopic range defined for marbles from Luc Yen and Quy Chau. Thus, the isotopic composition of ruby is apparently buffered by the host rock (Giuliani et al., 2003b). In contrast, the oxygen isotopic compositions of the Dak Nong sapphires are quite different from the rubies whatever their colour may be (Figure 13). The oxygen isotopic compositions are between 6 and $6.9 \%$ (average $\delta^{18} \mathrm{O}=6.6 \pm 0.4 \%$ o, $\mathrm{n}=5$ ) and are outside the range of the associated alkali basalts $\left(4.9<\delta^{18} \mathrm{O}<5.7 \%\right.$ ) , but within the range of syenitic rocks (Garnier et al., 2004).

\section{Conclusions}

Corundum is found in Vietnam in a number of different geological environments; these include amphibolite, gneiss, marble, basalt, pegmatite and metasomatized pegmatite. Of these, only two types of deposits are economically viable for gem production: marbles mined since 1983 in the Luc Yen, Yen Bai and Quy Chau districts, and basalts mined since 1991 in the Dak Lak, Lam Dong and Binh Thuan provinces. The appearance and characteristic features of the rubies and coloured sapphires from the Vietnamese gem deposits are generally related to their respective geological environments.

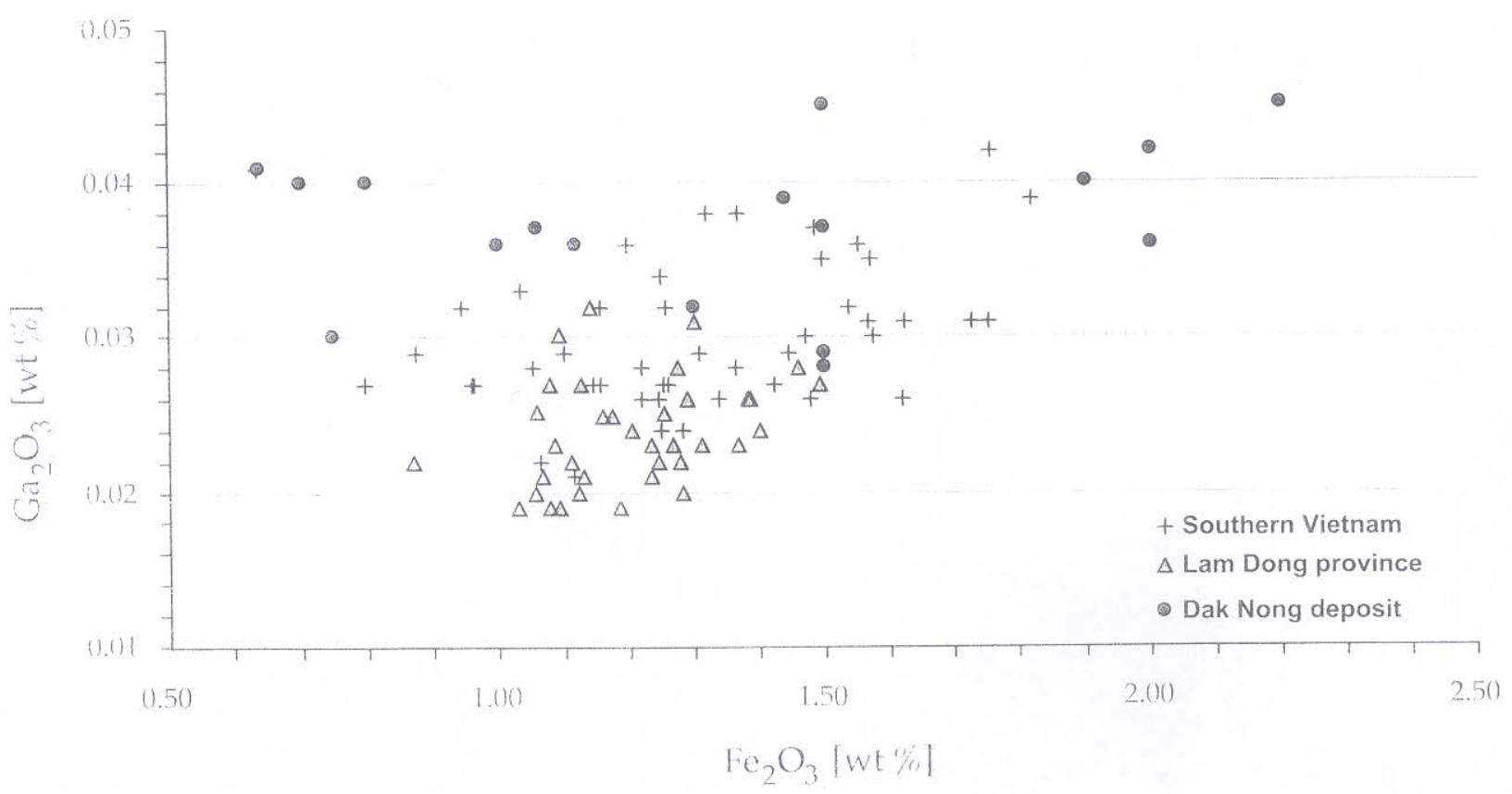

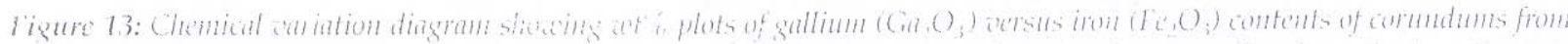

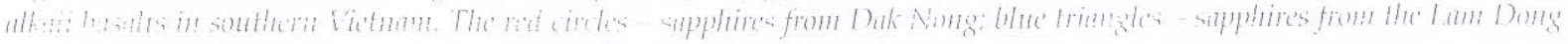

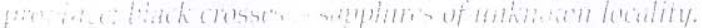




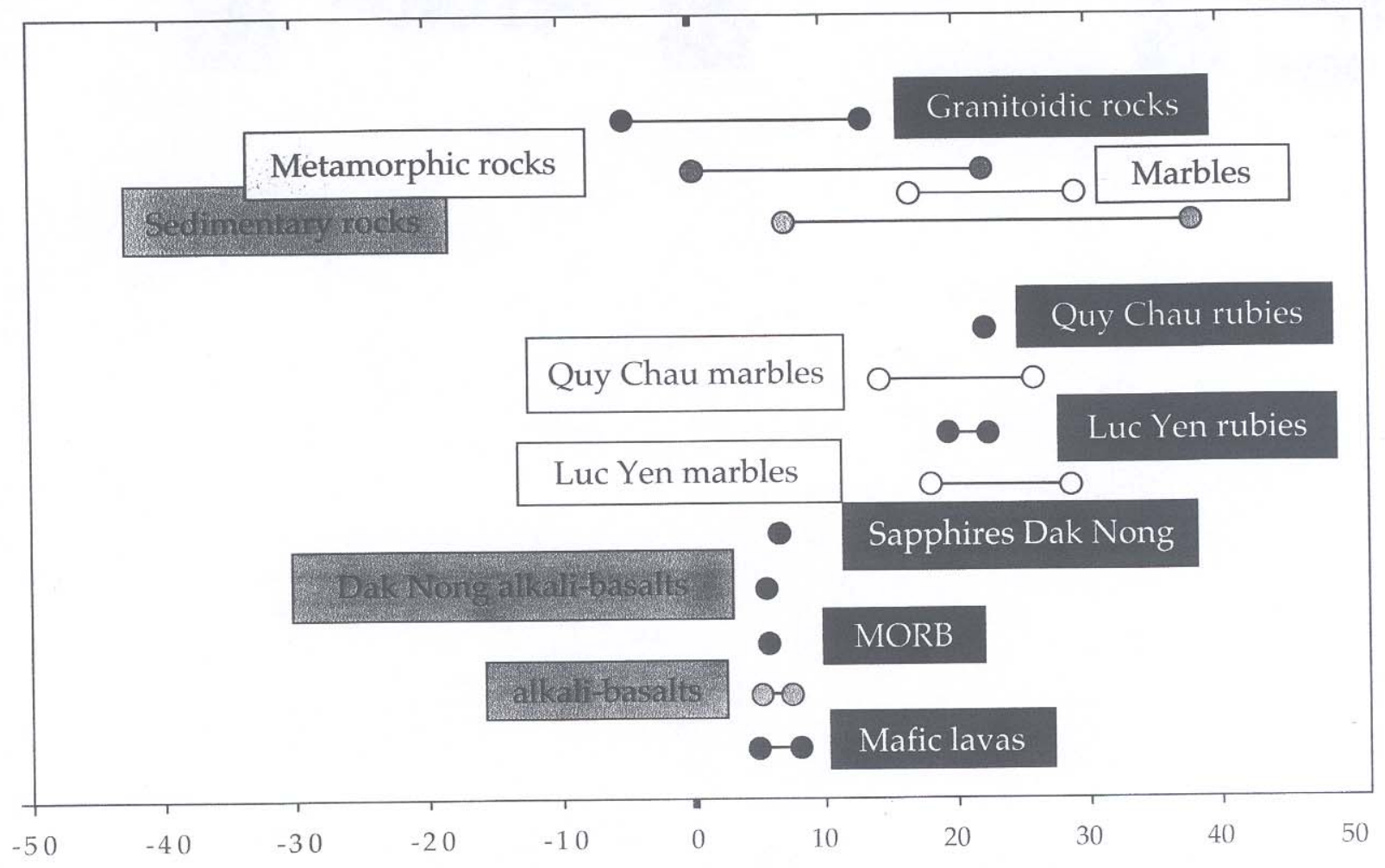

Figure 14: Oxygen isotopic composition of rubies from the Quy Chau and Luc Yen deposits versus 'BGY'-sapphires from Dak Long. The isotopic values of associated marbles and a range of basalts, sedimentary rocks and metamorphic rocks are shown for comparison (Hoefs, 1987).

Corundums exhibit consistent trace element variations which underline the diversity of their host-rocks. The $\mathrm{Cr}_{2} \mathrm{O}_{3} / \mathrm{Ga}_{2} \mathrm{O}_{3}$ versus $\mathrm{Fe}_{2} \mathrm{O}_{3} / \mathrm{TiO}_{2}$ geochemical diagram divides the corundums into three main fields which are discrete or partly overlapping: sapphires hosted by amphibolite, metapegmatite and gneiss, basalts, and rubies in marbles. A fourth domain contains blue and colourless sapphires found in the Yen Bai and Luc Yen placers and these have an unknown origin. Oxygen isotopic composition studies which clearly separate rubies in marble from sapphires in basalt will, with the use of classical gemmological techniques, probably help in deciphering the origin of these sapphires. Rubies in marbles commonly have distinctive fluid composition signatures, and studies of their inclusions and oxygen isotopic compositions could be used in the future for 'fingerprinting' and determining the origin of rubies found in placers.

\section{Acknowledgement}

The authors would like to thank Professor A.H. Rankin for review and many suggestions that improved the manuscript.

\section{References}

Dao, N.Q., Quang, V.X., Huy, N.Q. and Silvestre, J.-P., 1996. Discovery of diamond inclusions in rubies. C.R. Acad. Sci. Paris, 322, 515-22

Dao, N.Q., and Delaigue, L., 2000. Raman micro-spectrometry and its applications to the identification of inclusions in natural rubies. Analusis, 28, 34-8

Dao, N.Q., and Delaigue, L., 2001. Etudes des inclusions dans les rubis Vietnamiens par spectrométries optiques. International Workshop on Material Characterization by Solid State Spectroscopy: Gem and Mineral of Vietnam, Hanoi, pp 49-78

Dhamelincourt, P., Beny, J.M., Dubessy, J., Poty, B., 1979. Analyse d'inclusions fluides à la microsonde Mole à effet Raman. Bulletin de Minciralogie, 102, 60()-10

Garnier, V., Giuliani, G., Maluski, H., Ohnenstetter, D., Phan Trong, T., Hoang Quang, V., Pham Van, L., Vu Van, T., and Schwarz D., 2002. Ar-Ar ages in phlogopites from the marble-hosted ruby deposits in northern Vietnam: Evidence for Cenosoic ruby formation. Chem. Geol., 188, 33-49 
Garnier, V., Ohnenstetter, D., Giuliani, G., Fallick, A.E., Phan Trong, T., Hoáng Quang, V., Pham Van, L., and Schwarz, D., 2004. Age and genesis of corundum from the basaltic province of Dak Nong, Southern Vietnam. Mineralogical Magazine (submitted)

Giuliani, G., Dubessy, J., Banks, D., Hoáng Quang, V., Lhomme, T., Pironon, J., Garnier, V., Phan Trong, T., Pham Van, L., Ohnenstetter, D., and Schwarz, D., 2003a. $\mathrm{CO}_{2}-\mathrm{H}_{2} \mathrm{~S}-\mathrm{COS}-\mathrm{S}_{8}-\mathrm{AlO}(\mathrm{OH})$-bearing fluid inclusions in ruby from marble-hosted deposits in Luc Yen area, North Vietnam. Chem. Geol., 194, 167-85

Giuliani, G., Hoáng Quang, V., Lhomme, T., Dubessy, J., Banks, D., Fallick, A.E., Garnier, V., Ohnenstetter, D., Phan Trong, T., and Pham Van, L., 2003b. $\mathrm{CO}_{2}$ $\mathrm{H}_{2} \mathrm{~S}-\mathrm{COS}-\mathrm{S}_{8}-\mathrm{AlO}(\mathrm{OH})$-bearing fluid inclusions in ruby from marble-hosted deposits in Luc Yen and Quy Chau, North Vietnam., Abstract GAC-MACSEG Joint Annual Meeting, Vancouver, Canada, May 25-28, p.317.

Hoáng Quang, V., Giuliani, G., Phan Trong, T., Coget, P., France-Lanord, Ch., and Pham Van, L., 1999. Origin of ruby formation in Yên Bai Province. J. Geol., Series B 13-14, 118-23

Hoefs, J., 1987. Stable isotope geochemistry. 3rd ed. Springer-Verlag, Berlin-Heidelberg, $241 \mathrm{pp}$

Hofmeister, W., Dao, N.Q., and Quang V.X., 2001. Material characterization by solid state spectroscopy: gems and minerals of Vietnam. Proceedings International Workshop, Hanoi, 4-10 April 2001, 334 pp

Jolivet, L., Maluski, H., Beyssac, O., Goffé, B., Lepvrier, Cl., Phan Truong, T., and Nguyen Van, V., 1999. Oligocene-Miocene Bu Khang extensional gneiss dome in Vietnam: geodynamic implications. Geology, 27, 67-70)

Kane, R.E., McClure, S.F., Kammerling, R.C., Khoa, N.D., Mora, C. Repette, S.. Khai, ND., and Koivula, 1., 199!. Rubies and fancs sepptures fom Vietnam. Gem: \& Gemoley, 27, 136-55

Leloup, P.H., Amaud, N., Lacassin, R., Kienast, J.R., Harrison, T.M., Phan Trong, T., Replumaz, A., and Tapponnier, P., 2001. New constraints on the structure, thermochronology, and timing of the Ailao Shan-Red River shear zone, SE A sia. J. Geophlys. Ris, 106, (B4), 6683-732

Pham Van, L., 1949. Characteristics of inclusions of ruby' and sapphire from Luc Yen deposit. Journal of Geology, Serie A, N²52, 21-9

Pham Van, L., 2002. The study of the inclusions in Vietnamese rubies and sapphires by Raman spectroscopy method. Proceedings of the spectrum and optical conference of Vietnam, August 11-15, pp 113-19

Phan Trong, T., and Hoáng Quang, V., 1997. So Dô Kiên Tao Vunh Luc Yên. Geological map of Luc Yen, scale 1:200,000. Institute of Geological Sciences, Hanoi

Phan Trong, T., Leloup, P.H., Arnaud, N., and Lacassin, N., 1998. Formation of ruby in the Red River metamorphic zone. Proceedings of the National Centre for Natural Sciences and Technology, 10/1, 143-8

Schrötter, H.W., and Klöckner, H.W., 1979. Raman scattering cross section in gases and liquids. In: Raman spectroscopy of gases and liquids. Weber (Ed.), Berlin-Heidelberg-New York, Springer, 4, pp 123-66

Sharp, Z.D., 1990. A laser-based microanalytical method for the in situ determination of oxygen isotope ratios of silicates and oxides. Geochimica et Cosmochimica Acta, V. 54, 1353-7

Smith, C.P., Kammerling, R.C., Keller, A.S., Peretti, A., Scarratt, K.V., Khoa, N.D., and Repetto, S., 1995. Sapphire from Southern Vietnam. Gems \& Gemology, 31(3), 168-86

Stern, W.B., 1984. Zur Simultan Analyse von Silikaten (Hauptkomponenten, Spuren) mittels energie-dispersiver Röntgenfluoreszenz-Spectrometrie (EDSXFA). Fresenius Zeitschrift für Analaytische Chemie, $2560,1-9$

Sutherland, F.L., Coenraads, R.R., Schwarz, D., Raynor, L.R., Barron, B.J., and Webb, G.B., 2003. Al-rich diopside in alluvial ruby and corundum-bearing xenoliths, Australian and SE Asian basalt fields. Mineralogical Magazine, 67(4), 717-32

Stutherland, F.L., Hoskin, P.W.O., Fanning, C.M., and Coenrads, R.R., 1998a. Models of corundum origin from alkali basaltic terrains: a reappraisal. Contributions to Mineralogy and Petrology, 133, 356-72

Sutherland, F.L., Schwarı, D., Jobbins, E.A., Coenraads, R.R., and Webb, G., 1998b. Distinctive gem corundum suites from discrete basalt fields: a comparative study of Barrington, Australia, and West Pailin, Cambodia, gemfields. Journal of Gemmology, 26(2), 65-85 